\title{
The effect of MRET-nylon protective device on human subjects following exposure to RF phone radiation
}

\author{
Igor Smirnov, Ph.D. \\ Affiliation: Global Quantech, Inc., San Marcos, California \\ Email: igor @gqusa.com
}

\begin{abstract}
The purpose of this study was to examine with the help of thermal imaging the heat effects caused by the non-ionizing radiation of mobile phone and the protective properties of the MRET ${ }^{\circledR}$ Nylon polymer device in neutralizing or eliminating the thermal effects in the body. The current study shows that the exposure of human subjects to the microwave radiation of cellular phone results in the measured increase of the body temperature. It also showed that the installation of the MRET $^{\circledR}$-Nylon protective device on a RF phone significantly reduced or negated the thermal effects caused by RF phone and even leaded to the cooling pattern comparing to the standard cool-down state. Those result are well correlated with the accepted physical model which explains the relationship between the elevation of the body temperature with increased specific absorption rate of electromagnetic radiation (SAR) and increased blood perfusion rate (Green's function) usually following the human body exposure to EMR.
\end{abstract}

Keywords: Thermography, infrared camera, autonomic, sympathetic, parasympathetic, hypertonicity, fractal structure, polymer, noise field.

\section{INTRODUCTION}

The purpose of this study was to examine with the help of thermal imaging the heat effects caused by the non-ionizing radiation of mobile phone and the protective properties of the MRET ${ }^{\circledR}$-Nylon polymer device in neutralizing or eliminating the thermal effects in the body.

The thermal imaging is the imaging of the surface temperature of the skin by a non-contact infrared camera. When an infrared photo is captured it shows hot and cold patterns. The increased heat patterns correspond with the increased blood supply and the cooling patterns correspond with the decreased blood supply. The autonomic nervous system is in charge of the blood flow in capillaries, arterioles and venules. It has two branches: sympathetic and parasympathetic. The healthy sympathetic nervous system makes us respond to perceived threats or stresses (including EMR radiation) by increasing heart rate, respiration and decreasing blood supply to the skin and digestive system. The healthy parasympathetic nervous system decreases the heart rate, increases digestion and increases blood supply to the skin.
In the analysis of heat effects a temperature increase by $0.5^{\circ} \mathrm{C}$ or more is considered significant. However, an even lower temperature increase by $0.2^{\circ} \mathrm{C}-0.3^{\circ} \mathrm{C}$ in the hypothalamus leads to some changes in the thermoregulatory behavior [Adair E.R. at el, 1984]. One must be aware that thermal effects constitute only one aspect of problems caused by the exposure to EMR. Electromagnetic radiation, continuous consumption of prescription drugs, other toxins and stresses can weaken the autonomic nervous system, triggering excessive responses and imbalances which can cause further severe health problems. A number of studies confirm that there are numerous negative physiological effects related to the continuous exposure to EMR. These findings raise the issue of the bioaccumulation of the health related radiation effects when considering that the average individual frequently uses the cell and cordless phones.

The following thermal imaging study was conducted on seven subjects based on the comparative analysis of thermal images of their faces after the exposure to RF phone radiation without any protection and with the EMR protective MRET $^{\circledR}$-Nylon polymer device. The MRET $^{\circledR}$-Nylon device belongs to the new generation of electromagnetic radiation shielding materials and devices based on Molecular 
Resonance Effect Technology. The MRET ${ }^{\circledR}$-Nylon polymer material in the form of an oval chip was installed on mobile phone near the antenna. The MRET $^{\circledR}$-Nylon polymer compound has a special fractal geometric structure. Due to the fractal nanorings structure and enhanced piezoelectric properties of this compound, it generates random, subtle, low frequency oscillations when exposed to the external electromagnetic radiation (EMR). This polymer can significantly decrease the biological effects of electromagnetic radiation, both thermal and nonthermal, by imposing the random low frequency oscillations (noise field) on RF waves [Smirnov I.V., 2006]. The theoretical concept of the electromagnetic noise field is related to the ability of the noise field to offset the thermal effects [Lai H., 2004; Zeng Q. L. at el., 2006]

Due to the fact that most of the tested subjects had different types of health problems and were continuously using prescription drugs, the results of this study provide new evidences regarding the reactions of people with exhausted and destabilized autonomic nervous systems to the exposure of mobile phone radiation.

\section{METHODS AND MATERIALS}

The study was conducted by Board Certified Medical Thermographer Dr. Linda Fickes, D.C., C.C.N. at Fickes Holistic Care Corp in Honolulu, Hawaii. All thermal imaging was conducted using standard thermography procedures, as per the guidelines from the Standards and Protocols in Clinical Thermographic Imaging released by the International Academy of Clinical Thermography [IACT]. All tests were conducted using Infrared Scanner Model MHS 5000 , cellular phone model Motorola V325I (SAR value of $2.0 \mathrm{~W} / \mathrm{kg}$ averaged over ten grams of tissue). MRET-Nylon and MRET-Shield (in the last case) EMR protective devices were installed near the internal antenna of the cell phone. The MRET-Nylon device belongs to the new generation of electromagnetic radiation protective materials and devices based on Molecular Resonance Effect Technology. The EMR protective device MRETShield is covered with US Patent "Electromagnetic radiation Shielding Material and Device." The study was conducted on seven subjects having different types of health problems and continuously using prescription drugs.

The experiments were conducted according to the following protocol. The first image was captured following the standard 20 minutes cool-down of the subject in order to get a baseline for comparison with the image taken immediately after the same subject talked on the unprotected cell phone. The second image was captured after the subject talked on the unprotected cellular phone for 15 minutes. The third image was captured after a 20 minute standard cooldown to get the second baseline for comparison with the image taken immediately after the same subject talked for 15 minutes on the cell phone protected with MRET-Nylon device. The fourth image was captured after the subject talked for 15 minutes on the same cellular phone with MRET-Nylon chip (weight 350 $\mathrm{mg}$ ) installed on the phone.

\section{RESULTS}

Subject No.1: The subject is suffering from high blood pressures and uses a prescription drug Amlodipine on a regular daily basis. The image after the first standard cool-down demonstrated the existence of heat patterns in dental area of the subject.

The comparison of the first two images shows that following the use of an unprotected cell phone the thermal patterns are basically the same as prior to the use as seen on the image of the first standard cool-down. There was observed a decrease of heat in the thyroid gland area under the chin by $0.5^{\circ} \mathrm{C}$ (images $1 \& 2$, circle 1). 
2. Anterior Cranial Facial after Talking on an Unprotected Cell Phone for 15 minutes

\begin{tabular}{|c|c|c|c|c|c|c|c|c|c|c|c|c|c|}
\hline & 1 & 2 & 3 & 4 & 5 & 6 & & 1 & 2 & 3 & 4 & 5 & 6 \\
\hline Type & Circle & $\begin{array}{l}\text { Non } \\
\mathrm{e}\end{array}$ & Circle & $\begin{array}{l}\text { Non } \\
e^{-}\end{array}$ & Circle & None & Type & Circle & $\begin{array}{l}\text { Non } \\
\mathrm{e}\end{array}$ & Circle & $\begin{array}{l}\text { Non } \\
\text { e }\end{array}$ & Circle & None \\
\hline Maximum & $34.1^{\circ} \mathrm{C}$ & & $34.2^{\circ} \mathrm{C}$ & & $33.5^{\circ} \mathrm{C}$ & & Maximum & $33.6^{\circ} \mathrm{C}$ & & $33.9^{\circ} \mathrm{C}$ & & $33.4^{\circ} \mathrm{C}$ & \\
\hline Average & $33.1^{\circ} \mathrm{C}$ & & $33.0^{\circ} \mathrm{C}$ & & $32.8^{\circ} \mathrm{C}$ & & Average & $32.6^{\circ} \mathrm{C}$ & & $32.9^{\circ} \mathrm{C}$ & & $32.6^{\circ} \mathrm{C}$ & \\
\hline Minimum & $31.9^{\circ} \mathrm{C}$ & & $31.8^{\circ} \mathrm{C}$ & & $31.7^{\circ} \mathrm{C}$ & & Minimum & $31.0^{\circ} \mathrm{C}$ & & $31.7^{\circ} \mathrm{C}$ & & $31.4^{\circ} \mathrm{C}$ & \\
\hline Std. Dev & 0.521 & & 0.572 & & 0.397 & & Std. Dev & 0.507 & & 0.480 & & 0.452 & \\
\hline
\end{tabular}

1. Anterior Cranial Facial after First standard Cool-down

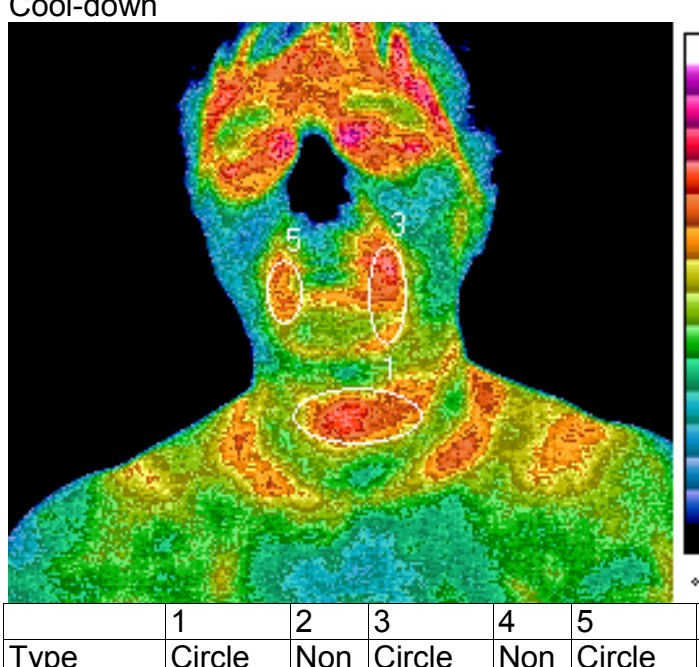

3. Anterior Cranial Facial after Second standard Cooldown
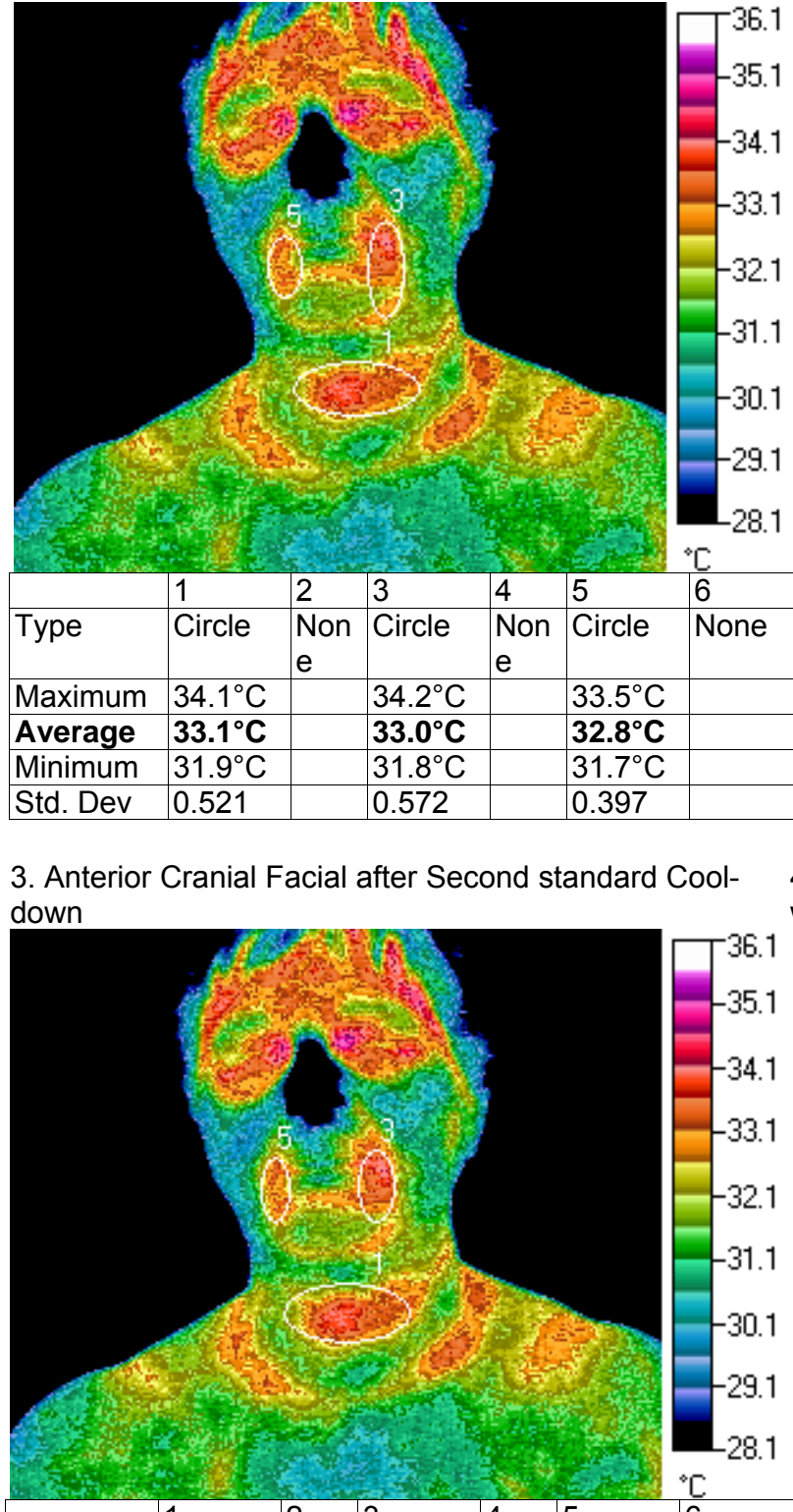

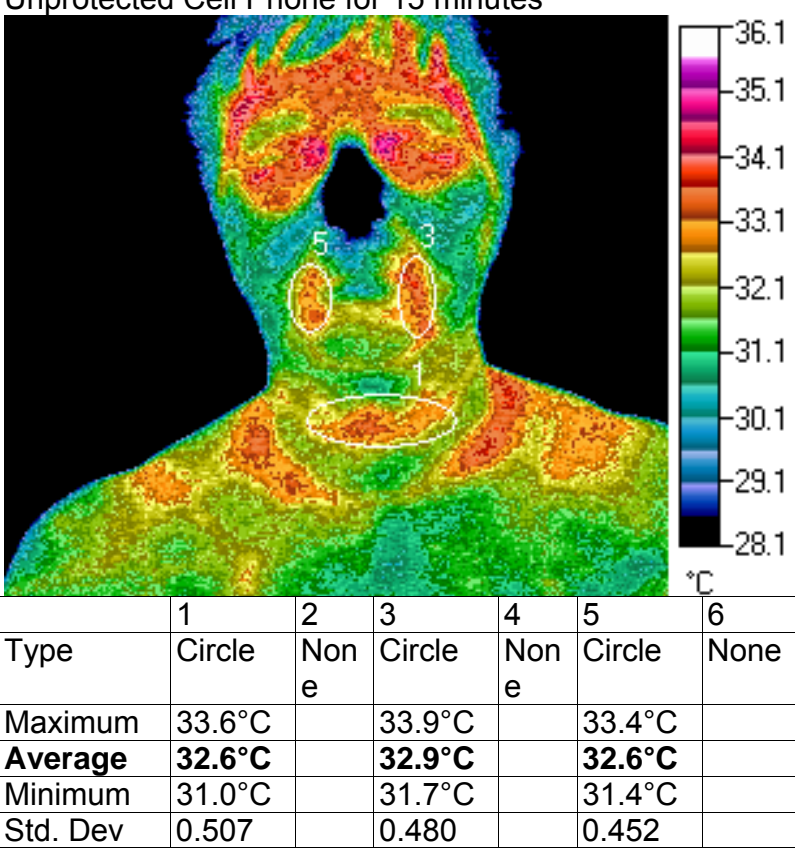

4. Anterior Cranial Facial after Talking on a Cell Phone with MRET-Nylon for 15 minutes

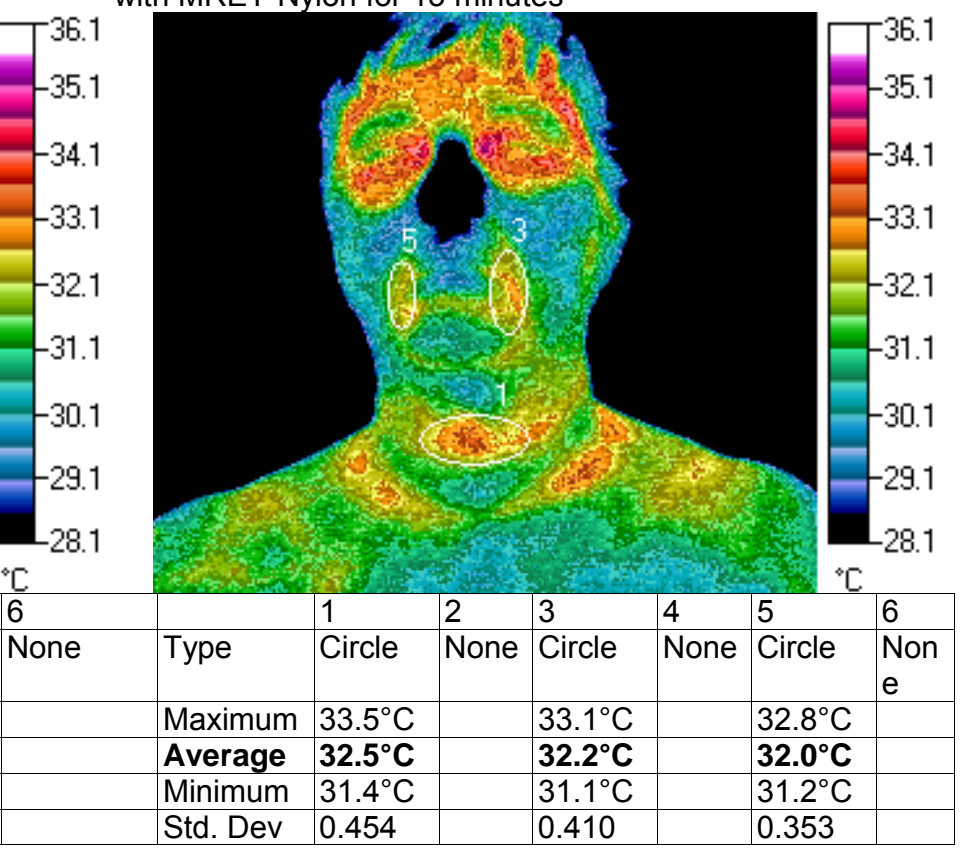

The comparison of the second two images shows that the installation of MRET-Nylon on a cellular phone significantly reduced the heat in the dental, neck and collarbone areas. Thus, the dental heat (inflammation from toxic metals and/or infections) did not increase following the exposure to the radiation from an unprotected cell phone, but the installation of MRET-Nylon significantly reduced this inflammation. The dental heat on the left side dropped by $1.1^{\circ} \mathrm{C}$ (images $3 \& 4$, circle 3 ) and the dental heat on the 
right side dropped by $0.8^{\circ} \mathrm{C}$ (images $3 \& 4$, circle 5) comparing with the second standard cool-down. The

1. Lateral Left Cranial Facial after First standard Cool-down

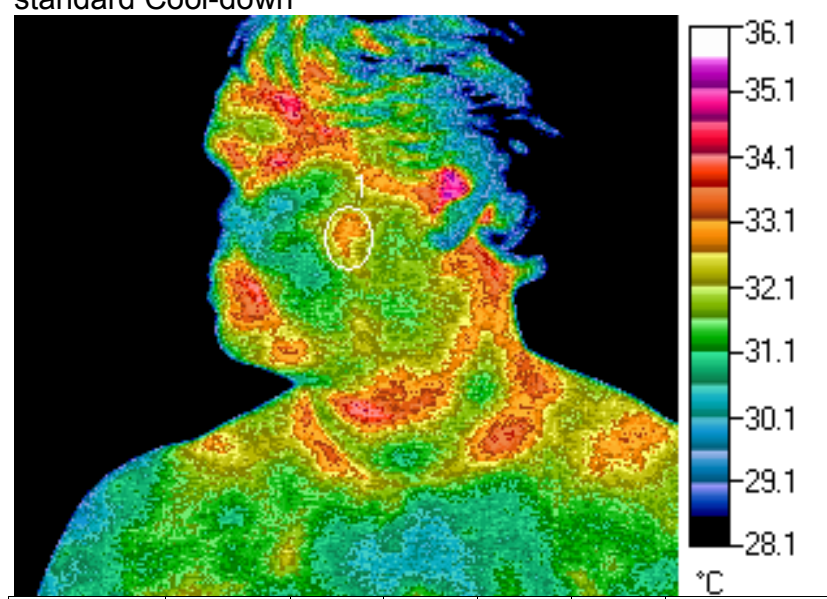

\begin{tabular}{|c|c|c|c|c|c|c|c|c|c|c|c|c|c|}
\hline & 1 & 2 & 3 & 4 & 5 & 6 & & 1 & 2 & 3 & 4 & 5 & 6 \\
\hline Type & Circle & None & None & None & None & None & Type & Circle & None & None & None & None & None \\
\hline Maximum & $33.1^{\circ} \mathrm{C}$ & & & & & & Maximum & $33.2^{\circ} \mathrm{C}$ & & & & & \\
\hline Average & $32.4^{\circ} \mathrm{C}$ & & & & & & Average & $32.5^{\circ} \mathrm{C}$ & & & & & \\
\hline Minimum & $31.5^{\circ} \mathrm{C}$ & & & & & & Minimum & $31.7^{\circ} \mathrm{C}$ & & & & & \\
\hline Std. Dev & 0.352 & & & & & & Std. Dev & 0.305 & & & & & \\
\hline
\end{tabular}

3. Lateral Left Cranial Facial after Second standard Cool-down

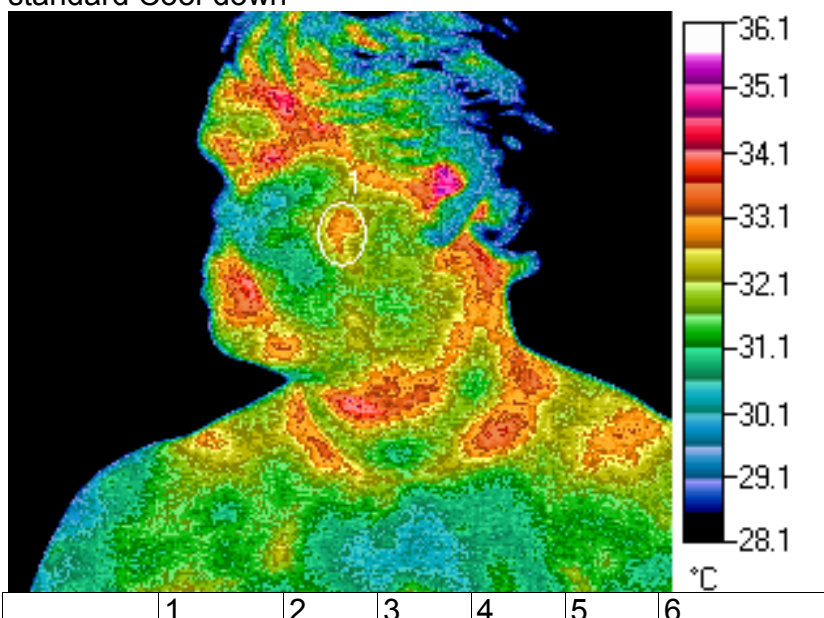

\begin{tabular}{|l|l|l|l|l|l|l|}
\hline & 1 & 2 & 3 & 4 & 5 & 6 \\
\hline Type & Circle & None & None & None & None & None \\
\hline Maximum & $33.1^{\circ} \mathrm{C}$ & & & & & \\
\hline Average & $32.4^{\circ} \mathrm{C}$ & & & & & \\
\hline Minimum & $31.5^{\circ} \mathrm{C}$ & & & & & \\
\hline Std. Dev & 0.352 & & & & & \\
\hline
\end{tabular}

The subject talked on cell phone using her left ear. The comparison of the first two images shows that on the left side the heat increased significantly by $0.5^{\circ} \mathrm{C}$ (images $1 \& 2$, color scale) in the neck and clavicle areas following the talk on an unprotected cell phone. temperature in the thyroid gland under the chin decreases by $0.5^{\circ} \mathrm{C}$ (images $3 \& 4$, circle 1 ).

2. Lateral Left Cranial Facial after Talking on an Unprotected Cell Phone for 15 minutes

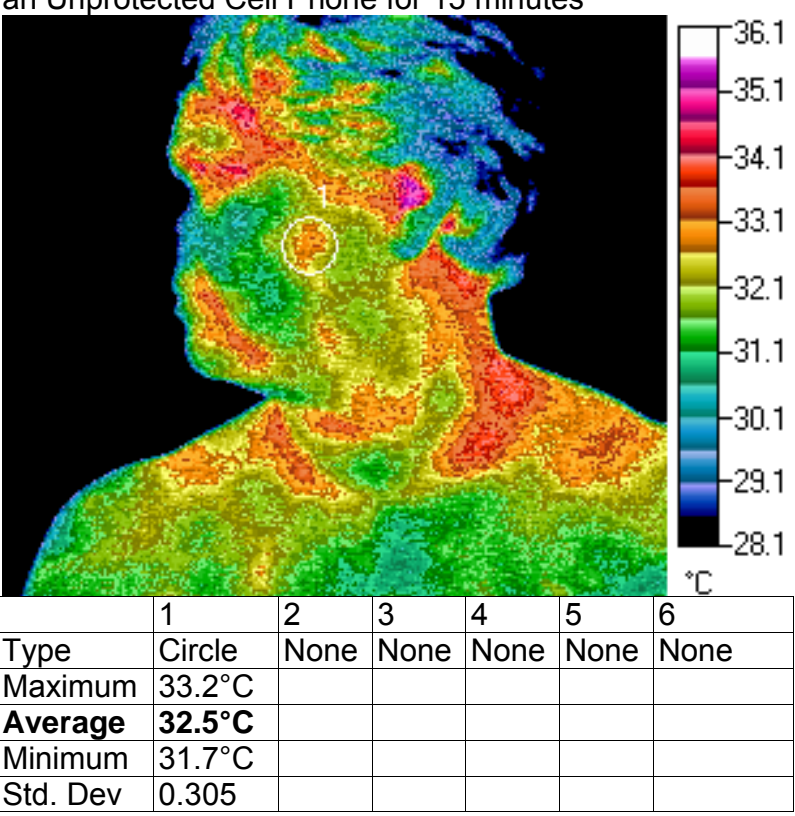

4. Lateral Left Cranial Facial after Talking on a

Cell Phone with MRET-Nylon for 15 minutes

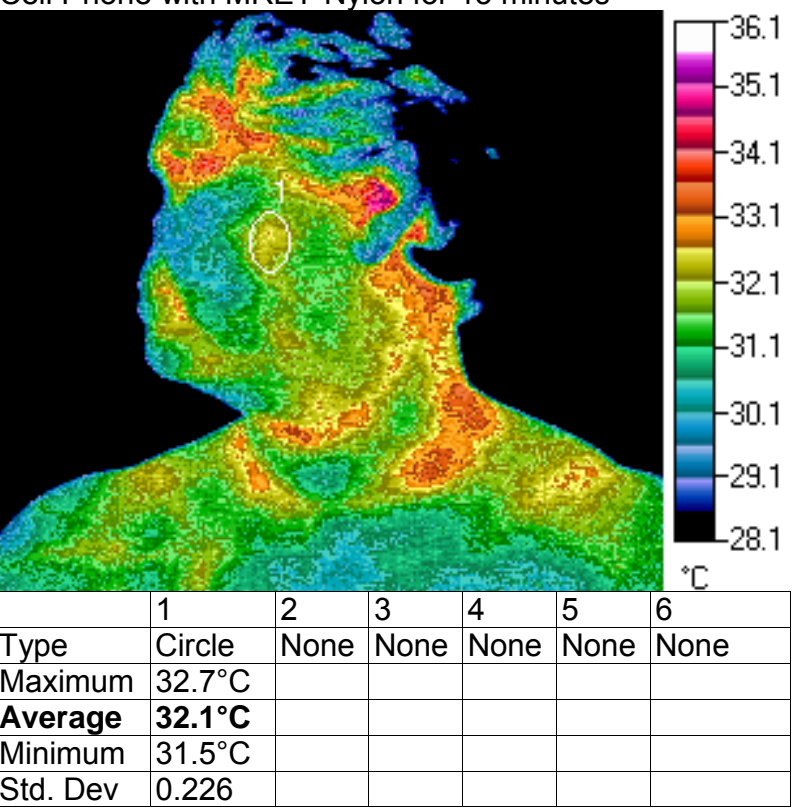

The comparison of the second two images shows that after the installation of MRET-Nylon device on a cell phone the heat reduced, especially in the dental area by $1.0^{\circ} \mathrm{C}-1.2^{\circ} \mathrm{C}$ (images $3 \& 4$, color scale) and in the thyroid gland under the chin by $1.0^{\circ} \mathrm{C}$ 
(images $3 \& 4$, color scale). The application of MRETNylon also cooled down the inflamed parotid salivary

1. Lateral Right Cranial Facial after First standard Cool-down

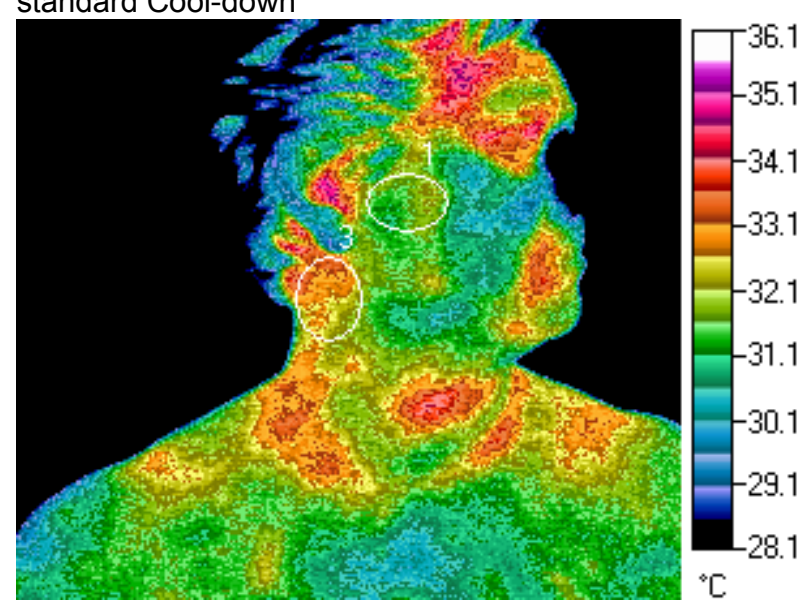

gland near the left ear by $0.3^{\circ} \mathrm{C}$ (images $3 \& 4$, circle 1).

2. Lateral Right Cranial Facial after Talking on an Unprotected Cell Phone for 15 minutes

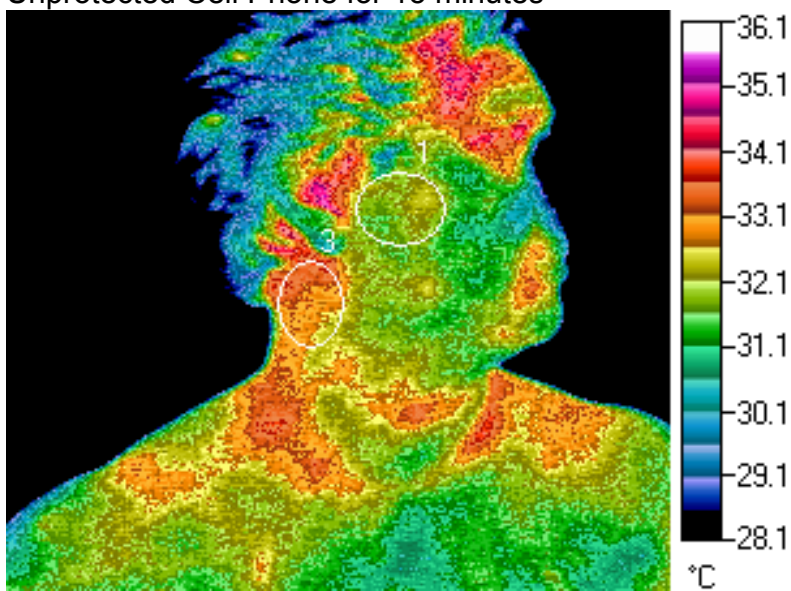

\begin{tabular}{|c|c|c|c|c|c|c|c|c|c|c|c|c|c|}
\hline & 1 & 2 & 3 & 4 & 5 & 6 & & 1 & 2 & 3 & 4 & 5 & 6 \\
\hline Type & Circle & None & Circle & None & None & None & Type & Circle & None & Circle & None & None & None \\
\hline Maximum & $32.4^{\circ} \mathrm{C}$ & & $33.7^{\circ} \mathrm{C}$ & & & & Maximum & $32.6^{\circ} \mathrm{C}$ & & $33.9^{\circ} \mathrm{C}$ & & & \\
\hline Average & $31.6^{\circ} \mathrm{C}$ & & $32.7^{\circ} \mathrm{C}$ & & & & Average & $31.9^{\circ} \mathrm{C}$ & & $33.0^{\circ} \mathrm{C}$ & & & \\
\hline Minimum & $30.9^{\circ} \mathrm{C}$ & & $31.5^{\circ} \mathrm{C}$ & & & & Minimum & $31.0^{\circ} \mathrm{C}$ & & $32.1^{\circ} \mathrm{C}$ & & & \\
\hline Std. Dev & 0.296 & & 0.445 & & & & Std. Dev & 0.270 & & 0.377 & & & \\
\hline
\end{tabular}

3. Lateral Right Cranial Facial after Second standard Cool-down

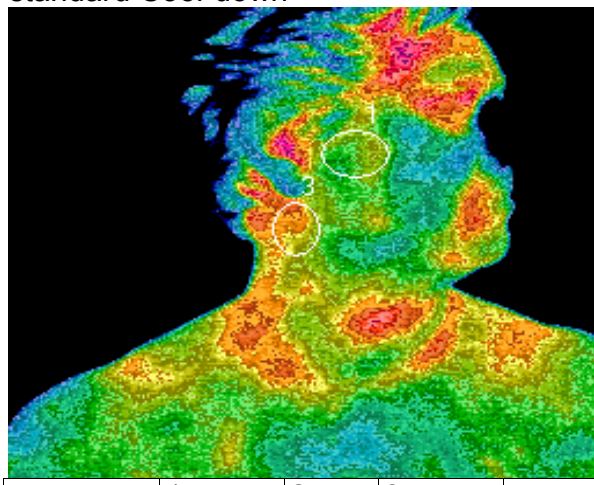

4. Lateral Right Cranial Facial after Talking on a Cell Phone with MRET-Nylon for 15 minutes

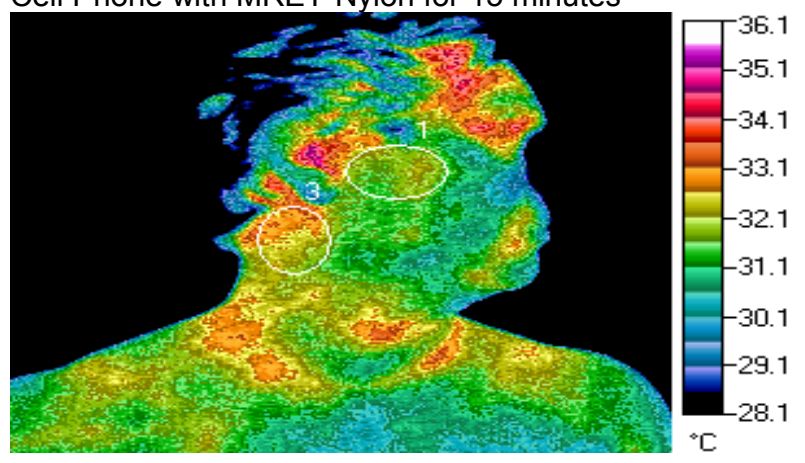

\begin{tabular}{|c|c|c|c|c|c|c|c|c|c|c|c|c|c|}
\hline & 1 & 2 & 3 & 4 & 5 & 6 & & 1 & 2 & 3 & 4 & 5 & 6 \\
\hline Type & Circle & None & Circle & None & None & None & Type & Circle & None & Circle & None & None & None \\
\hline Maximum & $32.4^{\circ} \mathrm{C}$ & & $33.5^{\circ} \mathrm{C}$ & & & & Maximum & $32.4^{\circ} \mathrm{C}$ & & $33.5^{\circ} \mathrm{C}$ & & & \\
\hline Average & $31.6^{\circ} \mathrm{C}$ & & $32.6^{\circ} \mathrm{C}$ & & & & Average & $31.8^{\circ} \mathrm{C}$ & & $32.5^{\circ} \mathrm{C}$ & & & \\
\hline Minimum & $30.9^{\circ} \mathrm{C}$ & & $31.5^{\circ} \mathrm{C}$ & & & & Minimum & $30.8^{\circ} \mathrm{C}$ & & $31.4^{\circ} \mathrm{C}$ & & & \\
\hline Std. Dev & 0.298 & & 0.453 & & & & Std. Dev & 0.262 & & 0.446 & & & \\
\hline
\end{tabular}

On the right side the exposure to an unprotected cell phone also slightly increased the heat patterns. The application of MRET-Nylon chip reduced the heat, especially in the dental area by $1.0^{\circ} \mathrm{C}$ (images $3 \& 4$, color scale) and in the thyroid gland area under the chin by $0.5^{\circ} \mathrm{C}$ (images $3 \& 4$, color scale).
This experiment confirms the significant reduction of thermal effects and the improvement of thermal patterns in dental area, as well as in thyroid gland and lymphatics in neck and clavicle areas following the installation of MRET-Nylon device on a cell phone. 
Subject No.2:

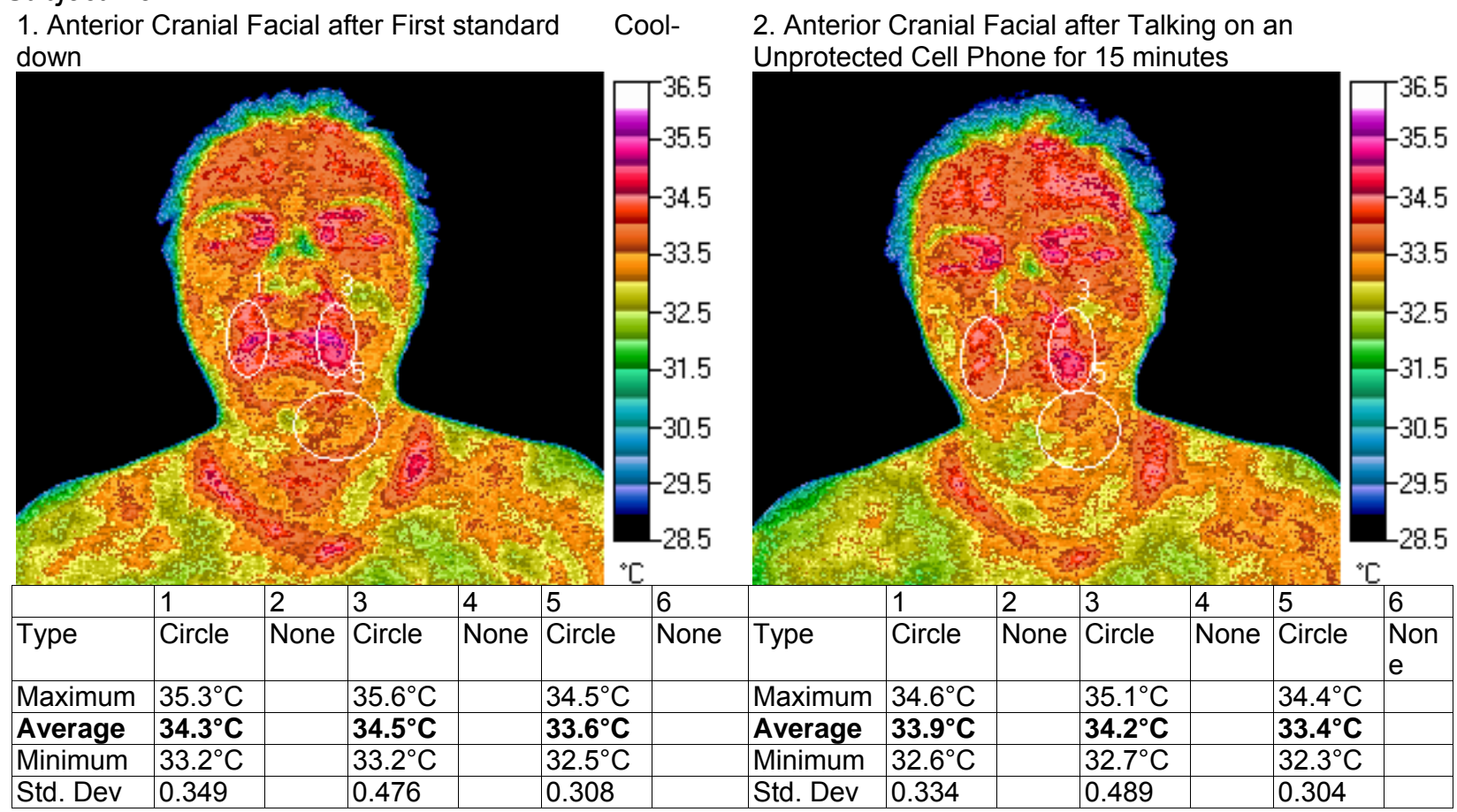

3. Anterior Cranial Facial after Second standard Cool-down

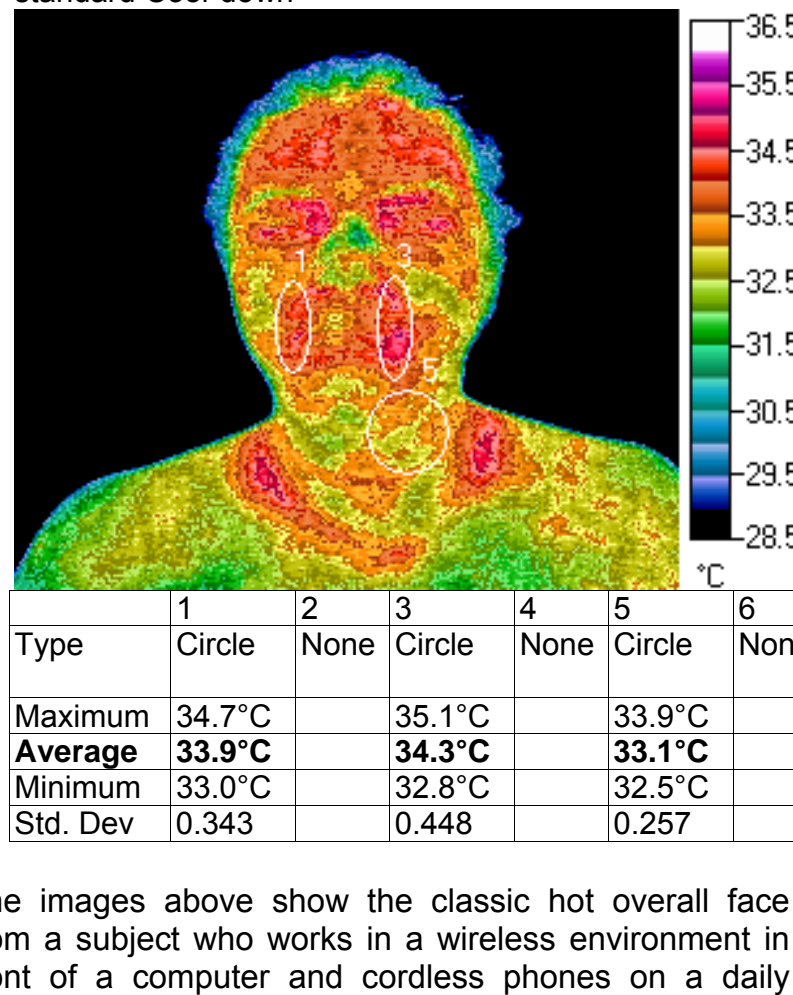

front of a computer and cordless phones on a daily basis. Her initial image shows extensive heat in all
4. Anterior Cranial Facial after Talking on a Cell Phone with MRET-Nylon for 15 minutes

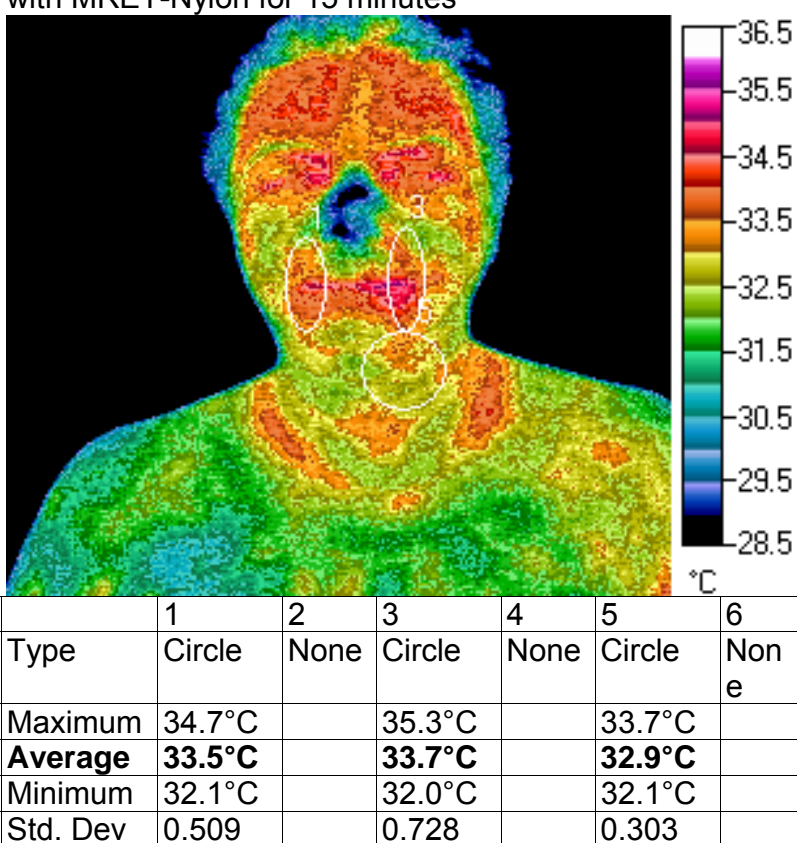

parasympathetic ganglia, nasal sinuses, dental area and lymphatic under the jaws.

We can see the same extensive heat patterns after the radiation exposure to an unprotected cell phone and after the second cool-down. However, after using a cell 
phone with the MRET-Nylon chip the heat significantly reduced especially in nasal sinuses, the mouth areas, lymphatics under the jaws, neck, clavicles and chest areas. All temperature measurements dropped: nasal sinuses heat by $1.5^{\circ} \mathrm{C}-2.5^{\circ} \mathrm{C}$ (images $3 \& 4$, color scale), mouth heat on the right side by $0.4^{\circ} \mathrm{C}$ (images 3 $\& 4$, circle 1 ) and on the left side by $0.6^{\circ} \mathrm{C}$ (images $3 \& 4$, circle 3 ), and lymphatics heat under the jaws, neck, clavicles and chest areas dropped by $0.5^{\circ} \mathrm{C}-1.0^{\circ} \mathrm{C}$ (images $3 \& 4$, color scale).

2. Lateral Left Cranial Facial after Talking on an Unprotected Cell Phone for 15 minutes

1. Lateral Left Craniar

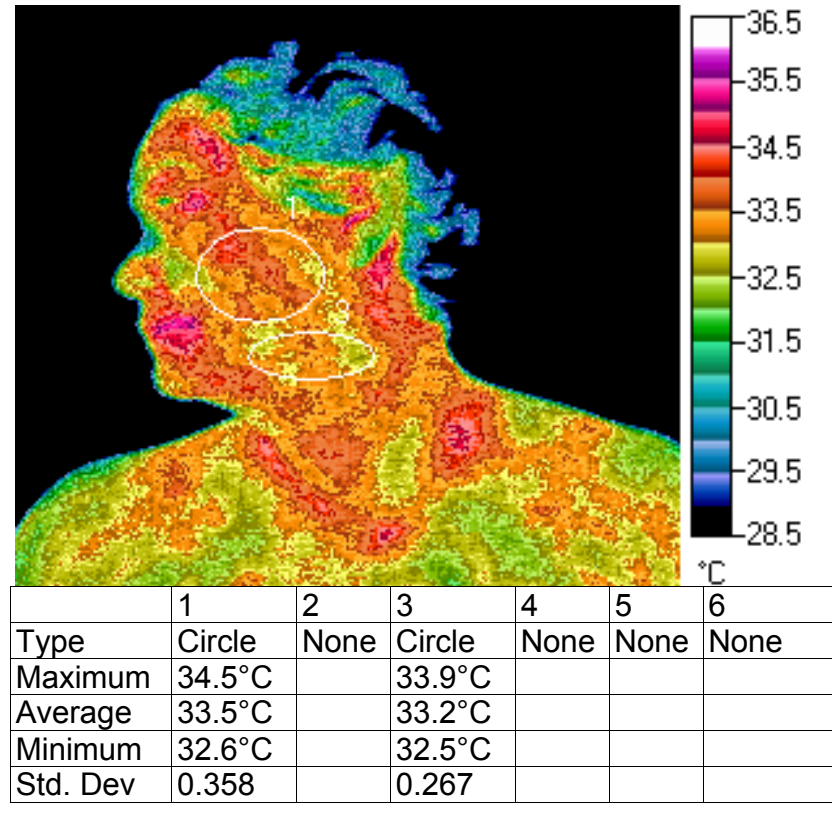

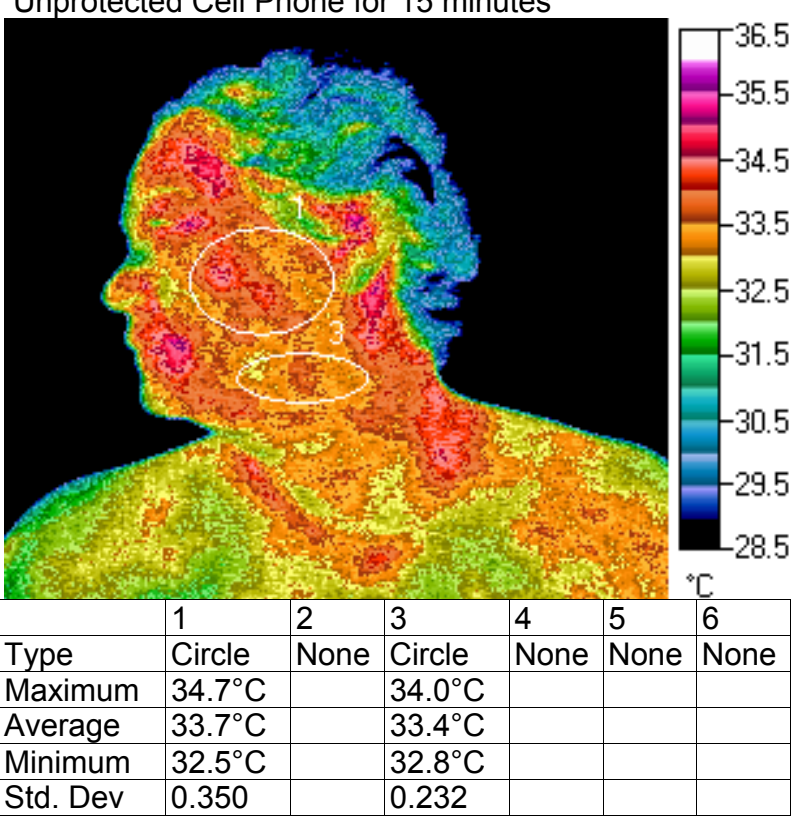

3. Lateral Left Cranial Facial after Second standard Cool-down

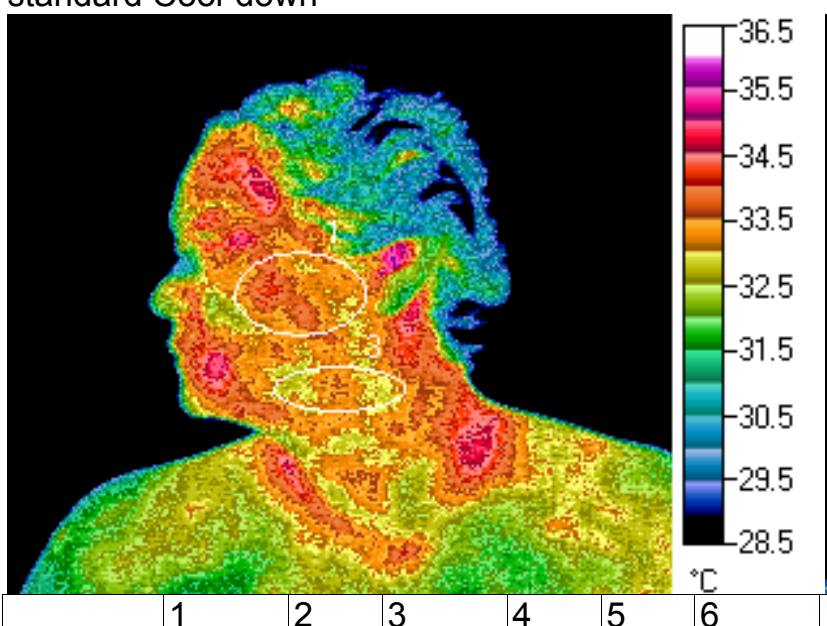

\begin{tabular}{|l|l|l|l|l|l|l|l|l|l|l|l|l|}
\hline Type & Circle & None & Circle & None & None None & Type & Circle & None Circle & None None None \\
\hline Maximum $34.2^{\circ} \mathrm{C}$ & $33.7^{\circ} \mathrm{C}$ & & & & Maximum & $34.2^{\circ} \mathrm{C}$ & $33.6^{\circ} \mathrm{C}$ & & & \\
\hline Average & $33.4^{\circ} \mathrm{C}$ & $33.1^{\circ} \mathrm{C}$ & & & Average & $33.2^{\circ} \mathrm{C}$ & $32.8^{\circ} \mathrm{C}$ & & & \\
\hline Minimum & $32.5^{\circ} \mathrm{C}$ & $32.6^{\circ} \mathrm{C}$ & & & Minimum & $32.3^{\circ} \mathrm{C}$ & $32.1^{\circ} \mathrm{C}$ & & & \\
\hline Std. Dev & 0.333 & 0.228 & & & & Std. Dev & 0.405 & & 0.266 & & & \\
\hline
\end{tabular}

4. Lateral Left Cranial Facial after Talking on a Cell Phone with MRET-Nylon for 15 minutes

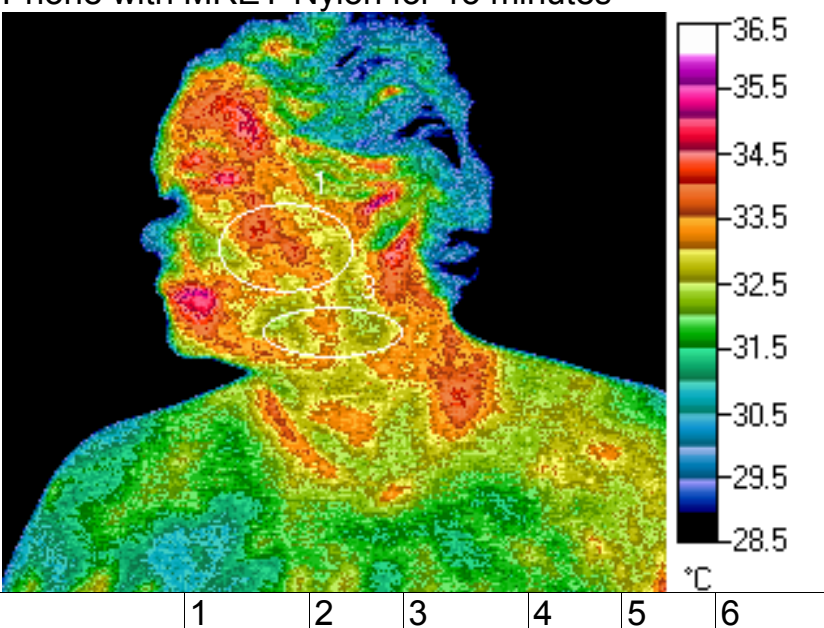

5

5 年5 
The subject talked on the phone using her left ear. Here we see heat from her daily severe exposure to radiation on both images following the standard cool-downs.

After exposure to an unprotected cell phone the heat patterns increased. The exposure to a cell phone with

MRET-Nylon chip significantly reduced the heat, especially in lymphatics on the low part of the face and in the neck, clavicle and chest areas which dropped by $0.5^{\circ} \mathrm{C}-1.0^{\circ} \mathrm{C}$ (images $3 \& 4$, color scale).

\section{Lateral Right Cranial Facial after Talking on an} Unprotected Cell Phone for 15 minutes

standard Cool-down

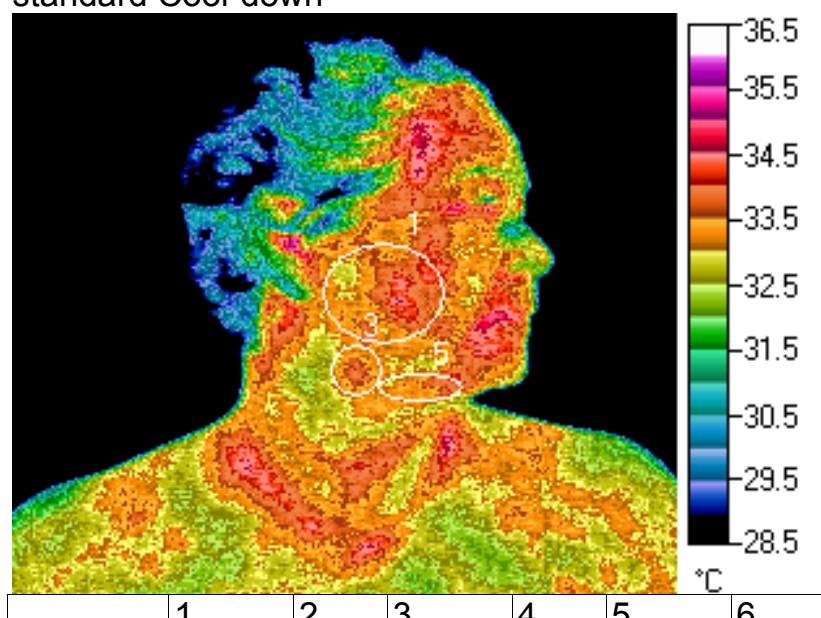

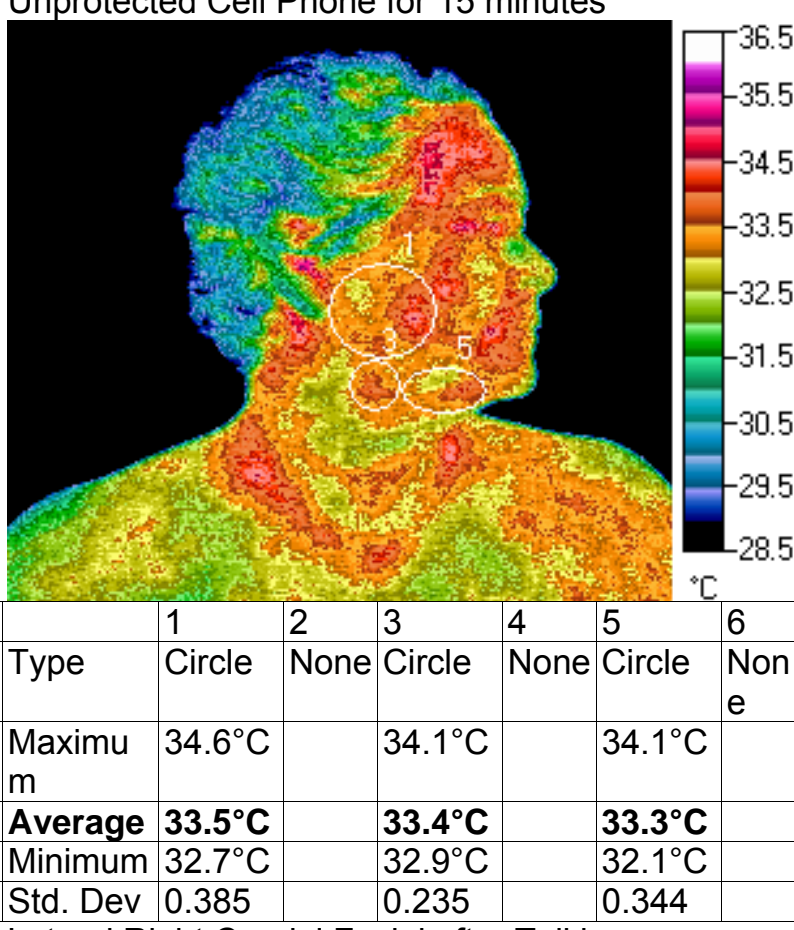

4. Lateral Right Cranial Facial after Talking on a Cell Phone with MRET-Nylon for 15 minutes

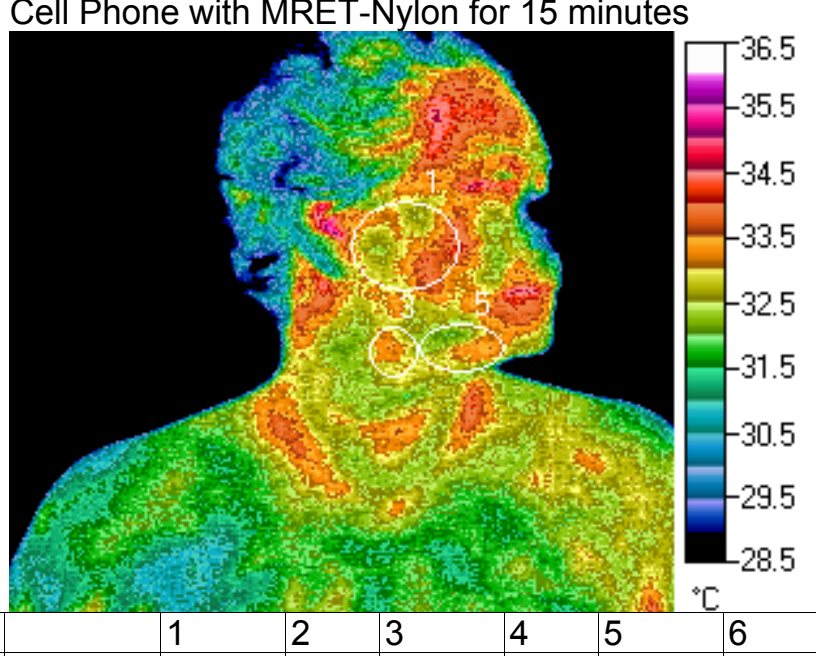

Type Circle None Circle None Circle None \begin{tabular}{|l|l|l|l|}
\hline Maximum $34.3^{\circ} \mathrm{C}$ & $33.6^{\circ} \mathrm{C}$ & $33.6^{\circ} \mathrm{C}$ \\
\hline
\end{tabular} \begin{tabular}{|l|l|l|}
\hline Average $33.2^{\circ} \mathrm{C}$ & $33.0^{\circ} \mathrm{C}$ & $32.7^{\circ} \mathrm{C}$
\end{tabular} \begin{tabular}{ll|l|l|} 
Minimum $32.2^{\circ} \mathrm{C}$ & $32.3^{\circ} \mathrm{C}$ & $30.9^{\circ} \mathrm{C}$
\end{tabular} Std. Dev 0.446 0.256 0.453 
The extensive heat patterns on the right side practically did not change after using an unprotected cell phone, but they significantly reduced following the application of the MRET-Nylon device to the cell phone. The comparison of the last two images shows significant cooling effects in nasal sinuses by $1.5^{\circ} \mathrm{C}-$ $2.5^{\circ} \mathrm{C}$ (images $3 \& 4$, color scale) and in lymphatics in the neck, clavicle and chest areas by $0.5^{\circ} \mathrm{C}-1.0^{\circ} \mathrm{C}$ (images $3 \& 4$, color scale).

This experiment shows that continuous daily exposure to EMR damages and exhausts the autonomic nervous system which was confirmed by abnormal overheated thermal patterns in a calm state after the standard 20 minutes cool-downs. The subject demonstrated extensive heat patterns in a calm state after standard cool-downs and after additional EMR stress from the exposure to an unprotected cell phone. The application of MRETNylon chip to a cell phone leaded to the significant reduction of thermal effects and the improvement of thermal patterns in nasal sinuses and mouth areas, as well as in thyroid gland and lymphatics under the jaws, neck, clavicle, and chest areas.

\section{Subject No.3:}

1. Anterior Cranial Facial after First standard Cool-down

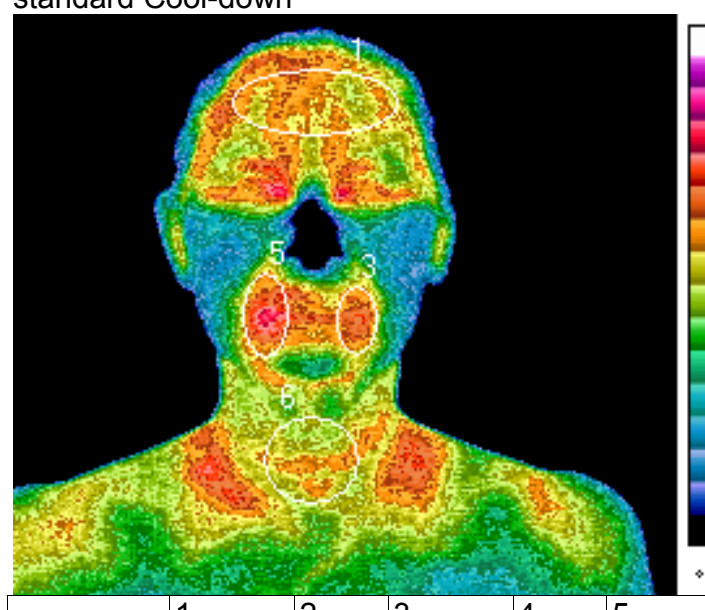

2. Anterior Cranial Facial after Talking on an Unprotected Cell Phone for 15 minutes

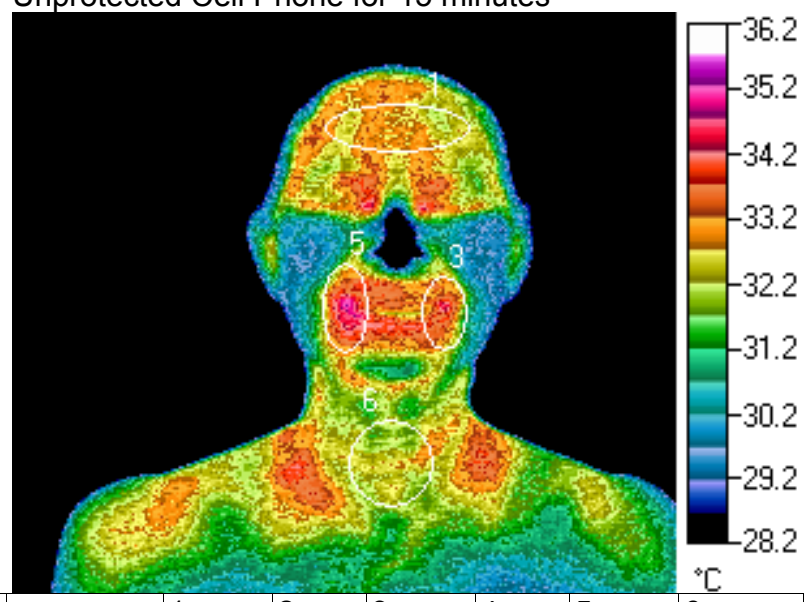

\begin{tabular}{|c|c|c|c|c|c|c|c|c|c|c|c|c|c|}
\hline & 1 & 2 & 3 & 4 & 5 & 6 & & 1 & 2 & 3 & 4 & 5 & 6 \\
\hline Type & Circle & None & Circle & None & Circle & Circle & Type & Circle & None & Circle & None & Circle & Circle \\
\hline Maximum & $33.6^{\circ} \mathrm{C}$ & & $33.9^{\circ} \mathrm{C}$ & & $34.7^{\circ} \mathrm{C}$ & $33.5^{\circ} \mathrm{C}$ & Maximum & $33.3^{\circ} \mathrm{C}$ & & $34.6^{\circ} \mathrm{C}$ & & $35.3^{\circ} \mathrm{C}$ & $33.4^{\circ} \mathrm{C}$ \\
\hline Average & $32.8^{\circ} \mathrm{C}$ & & $33.1^{\circ} \mathrm{C}$ & & $33.5^{\circ} \mathrm{C}$ & $32.5^{\circ} \mathrm{C}$ & Average & $32.7^{\circ} \mathrm{C}$ & & $33.0^{\circ} \mathrm{C}$ & & $33.6^{\circ} \mathrm{C}$ & $32.3^{\circ} \mathrm{C}$ \\
\hline Minimum & $32.1^{\circ} \mathrm{C}$ & & $31.7^{\circ} \mathrm{C}$ & & $32.1^{\circ} \mathrm{C}$ & $31.7^{\circ} \mathrm{C}$ & Minimum & $31.9^{\circ} \mathrm{C}$ & & $30.7^{\circ} \mathrm{C}$ & & $31.5^{\circ} \mathrm{C}$ & $31.5^{\circ} \mathrm{C}$ \\
\hline Std. Dev & 0.282 & & 0.410 & & 0.567 & 0.344 & Std. Dev & 0.274 & & 0.809 & & 0.731 & 0.337 \\
\hline
\end{tabular}


Am. J. Sci. Ind. Res., 2011, 2(4): 616-641

3. Anterior Cranial Facial after Second standard Cool-down

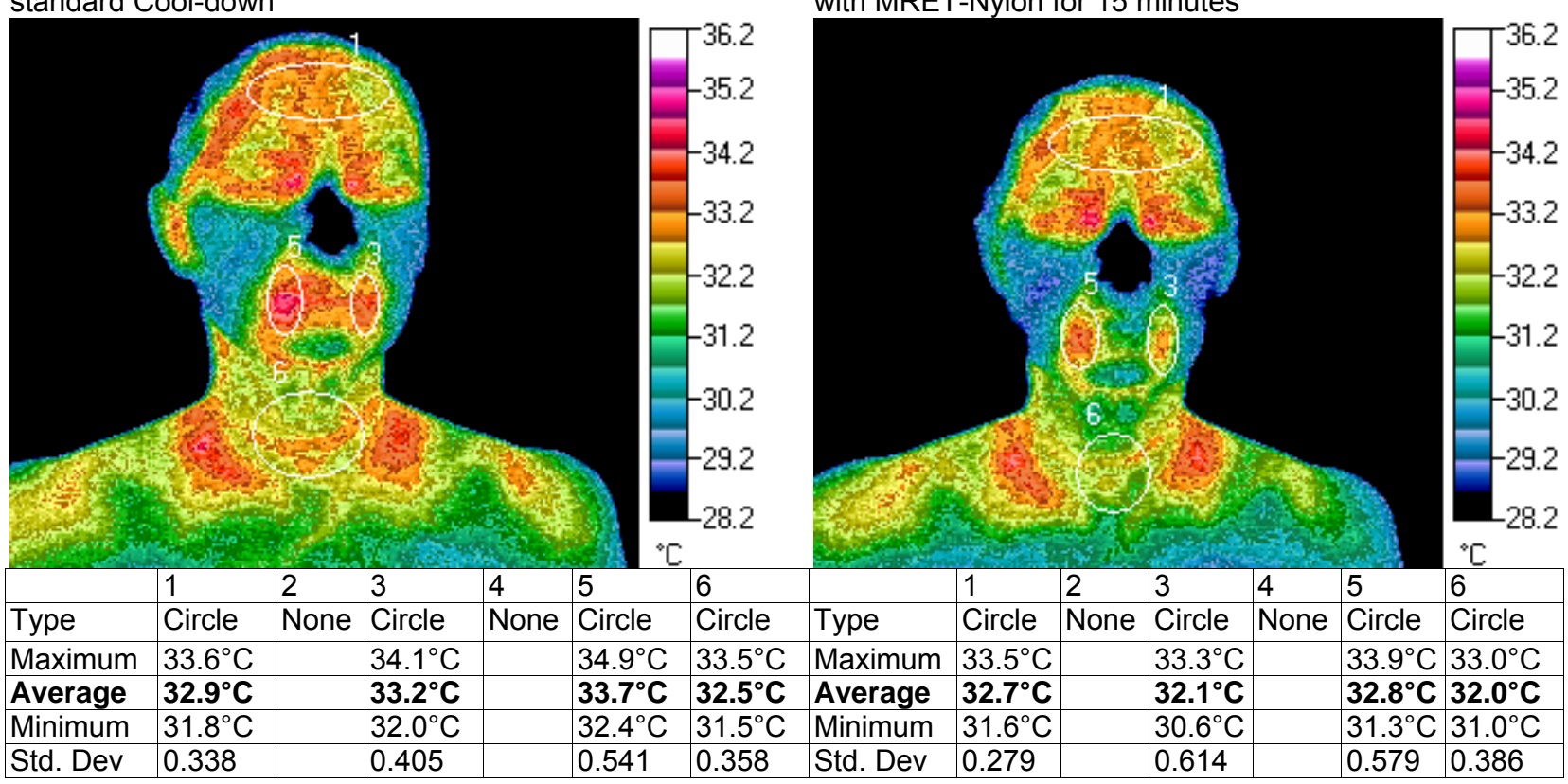

4. Anterior Cranial Facial after Talking on a Cell Phone with MRET-Nylon for 15 minutes
The subject is diabetic, has hormone imbalances and takes a number of prescription drugs such as Glimerpride, Metformin, Januvia, Lisinopril and Simvastatin. The image after the first standard cooldown demonstrated the existence of abnormal heat patterns in the dental area of the subject.

The comparison of the first two images does not show any significant changes in the thermal patterns after speaking on an unprotected cell phone.
The comparison of the second two images shows significant cooling patterns which appeared after speaking on a cell phone protected with the MRETNylon chip. The dental heat on the left side reduced by $1.1^{\circ} \mathrm{C}$ (images $3 \& 4$, circle 3 ) and on the right side by $0.9^{\circ} \mathrm{C}$ (images $3 \& 4$, circle 5 ). It was also observed significant cooling of lymphatics in neck area and in thyroid gland by $0.5^{\circ} \mathrm{C}$ (images $3 \& 4$, circle 6). 
1. Lateral Left Cranial Facial after First standard Cool-down

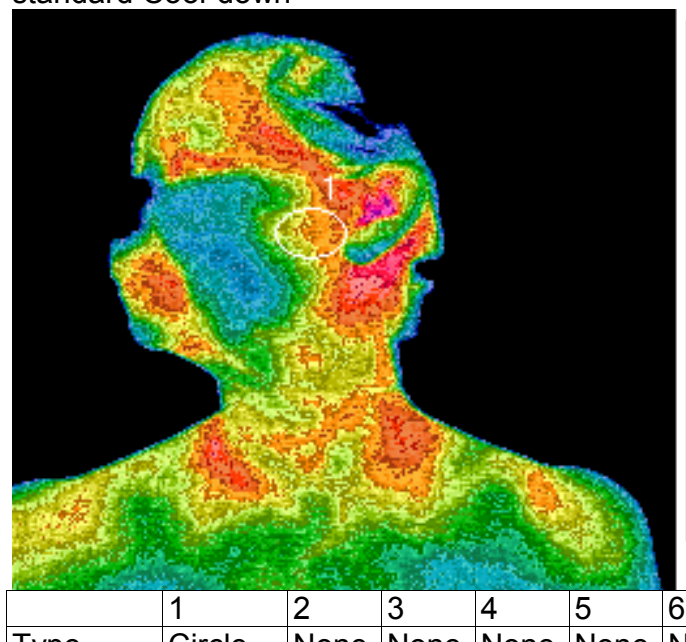

\begin{tabular}{l|l|l|l|l}
\hline Type & Circle & None & None None None None
\end{tabular}

Maximum $33.5^{\circ} \mathrm{C}$

Average $32.7^{\circ} \mathrm{C}$

Minimum $31.6^{\circ} \mathrm{C}$

Std. Dev 0.438

3. Lateral Left Cranial Facial after Second standard Cool-down

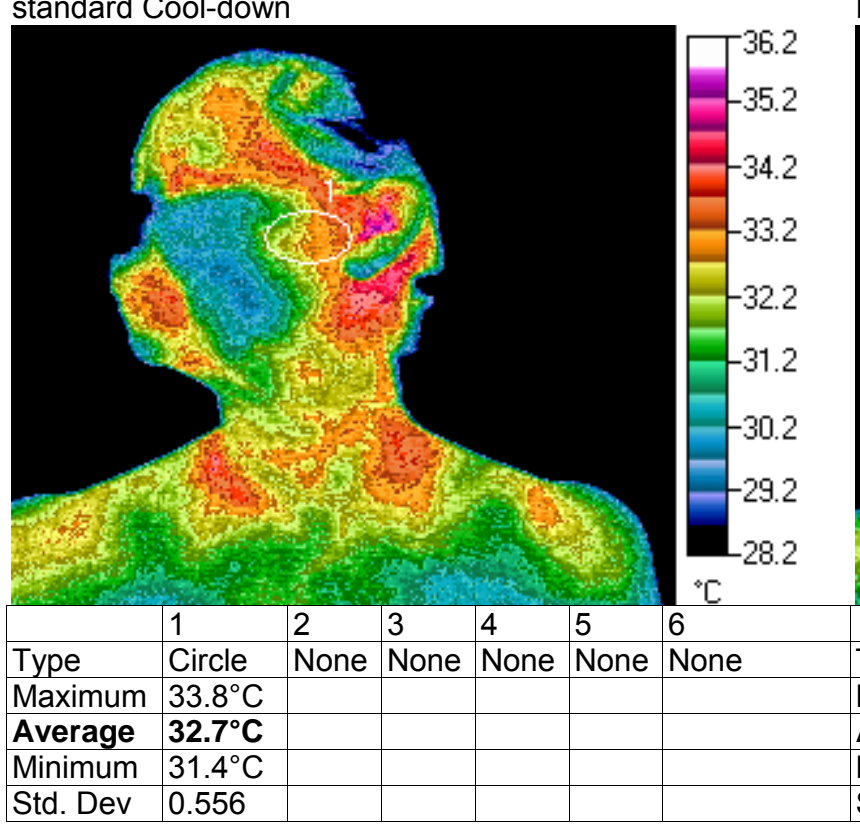

The subject talked on the phone using her right ear. Following the exposure to an unprotected cell phone this subject had a decrease of heat (abnormal reaction) in the left otic ganglia near the ear by $0.7^{\circ} \mathrm{C}$ (images $1 \& 2$, circle 1 ). Following the installation of the MRET-Nylon chip on a phone the heat in the left
2. Lateral Left Cranial Facial after Talking on an Unprotected Cell Phone for 15 minutes

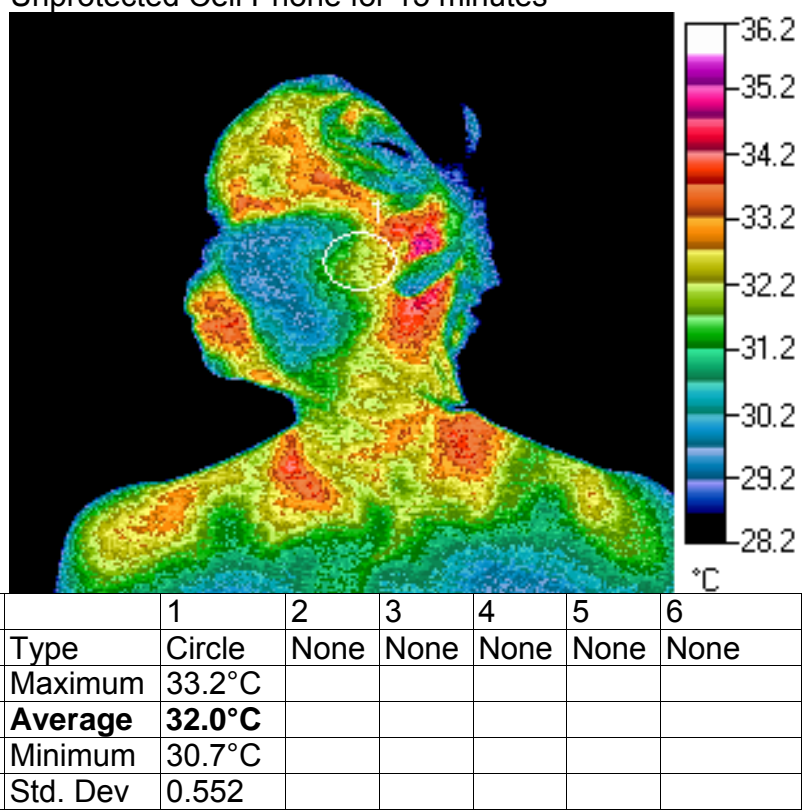

4. Lateral Left Cranial Facial after Talking on a Cell Phone with MRET-Nylon for 15 minutes

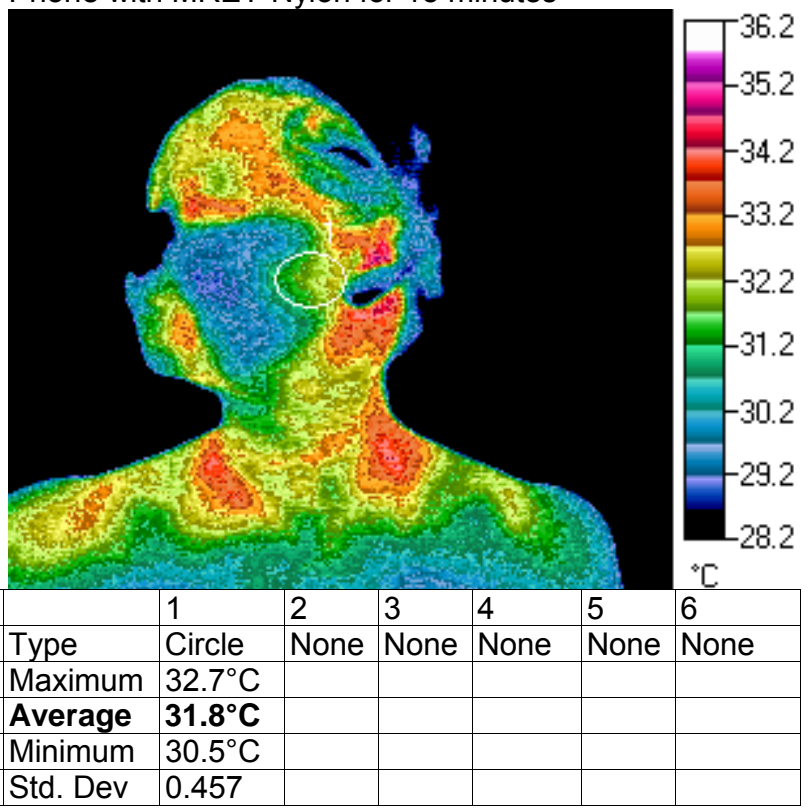

otic ganglia reduced even more by $0.9^{\circ} \mathrm{C}$ (images 3 \& 4 , circle 1). The significant reduction of heat patterns was observed in the dental area by $1.0^{\circ} \mathrm{C}$ (images 3 $\& 4$, color scale) and in neck area by $0.5^{\circ} \mathrm{C}$ (images 3 $\& 4$, color scale). 
1. Lateral Right Cranial Facial after First standard Cool-down

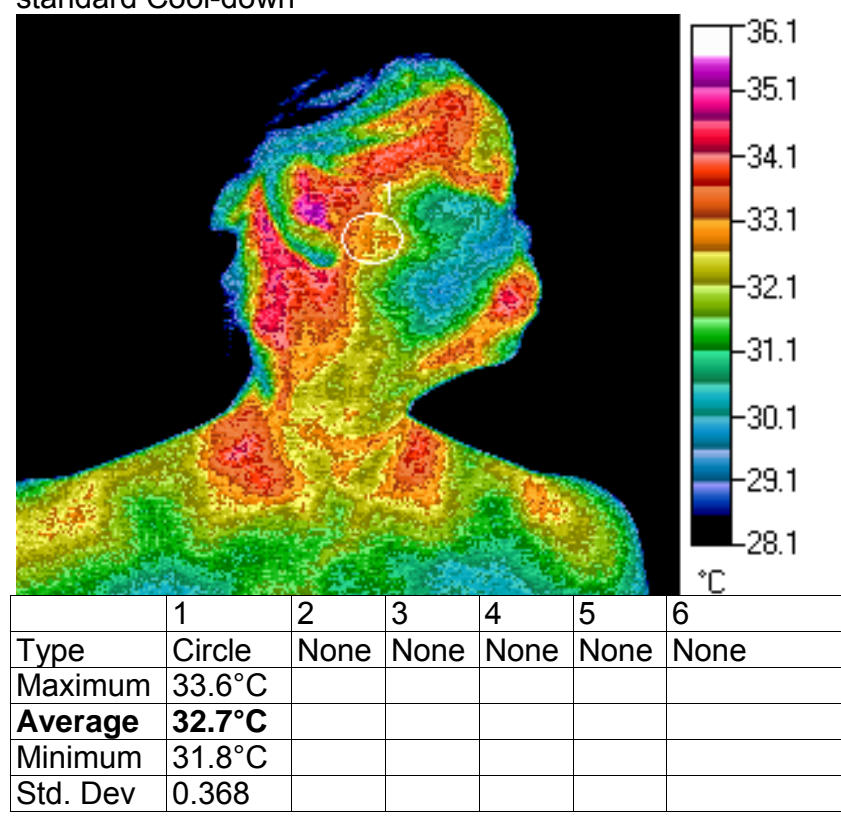

3. Lateral Right Cranial Facial after Second standard Cool-down

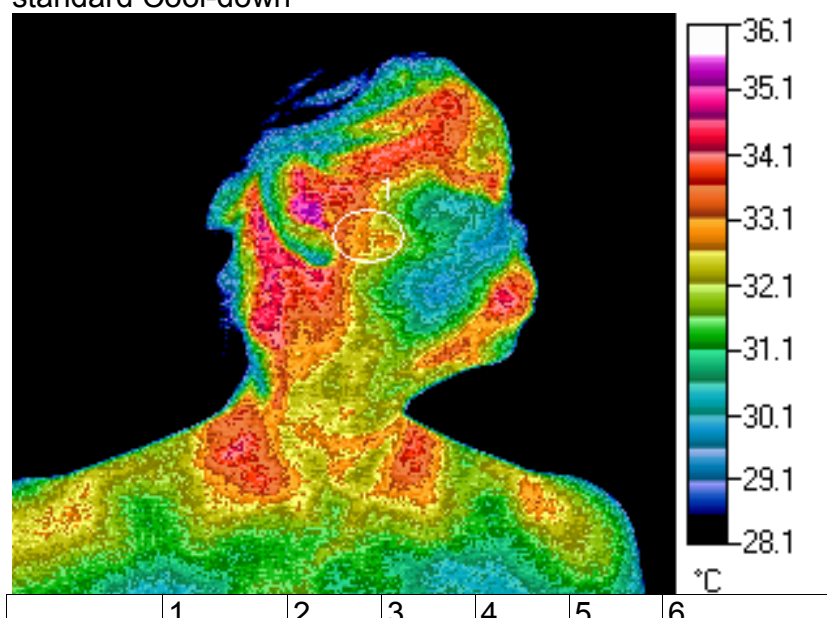

\begin{tabular}{|l|l|l|l|l|l|l|} 
& 1 & 2 & 3 & 4 & 5 & 6 \\
\hline Type & Circle & None & None & None & None & None \\
\hline Maximum & $33.6^{\circ} \mathrm{C}$ & & & & &
\end{tabular}

\begin{tabular}{|l|l|l|l|l|l|l|}
\hline Maximum & $33.6^{\circ} \mathrm{C}$ & & & & & \\
\hline Average & $32.7^{\circ} \mathrm{C}$ & & & & & \\
\hline Minimum & $31.7^{\circ} \mathrm{C}$ & & & & & \\
\hline Std & & &
\end{tabular}

$\begin{array}{ll}\text { Minimum } & 31.7^{\circ} \mathrm{C}\end{array}$

Std. Dev 0.438

The similar reactions were observed on the right side of the subject's head. There was a decrease in heat in the otic ganglia by $0.5^{\circ} \mathrm{C}$ (images $1 \& 2$, circle 1 ) after talking on an unprotected cell phone and the higher reduction of heat by $0.7^{\circ} \mathrm{C}$ (images $3 \& 4$, circle 1) following the exposure to MRET-Nylon protected cell phone. MRET-Nylon installation also
2. Lateral Right Cranial Facial after Talking on

Unprotected Cell Phone for 15 minutes

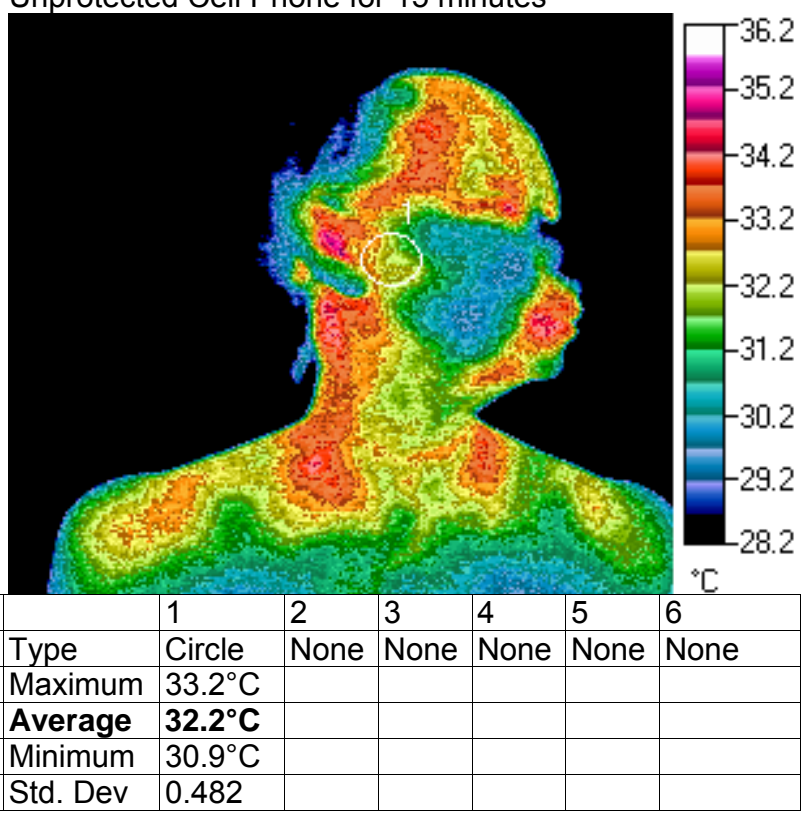

4. Lateral Right Cranial Facial after Talking on Cell Phone with MRET-Nylon for 15 minutes

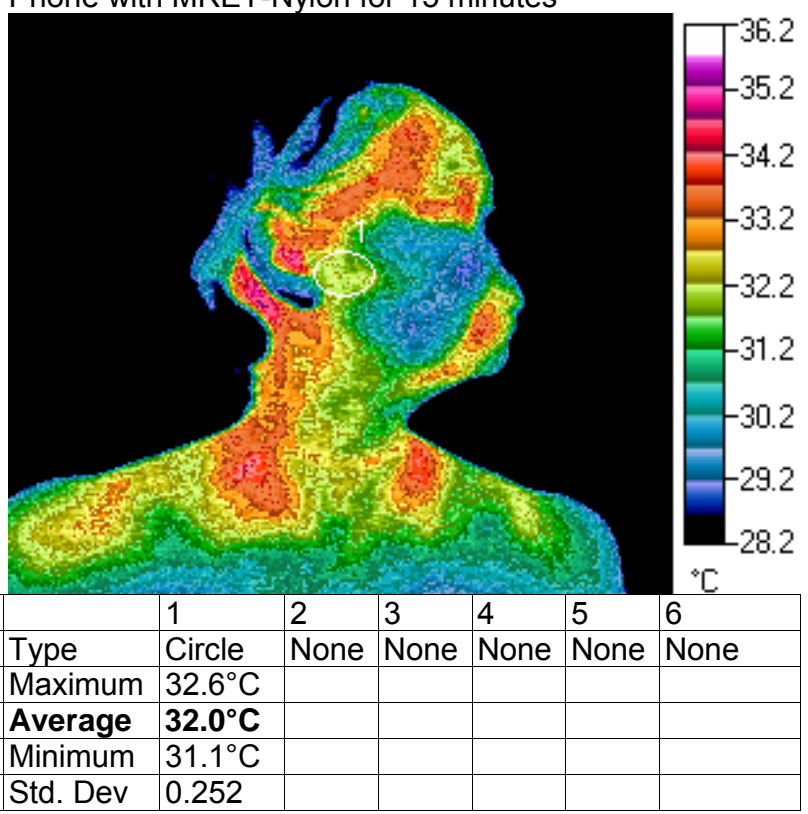

substantially reduced the heat in dental area and in the lymphatics in neck, ear and head areas by $0.5^{\circ} \mathrm{C}$ (images $3 \& 4$, color scale).

This experiment confirms the significant improvement of thermal patterns in dental area, as well as in thyroid gland and lymphatics in ears and neck areas 
after the application of the MRET-Nylon device to a Subject No.4:

1. Anterior Cranial Facial after First standard Cool-down

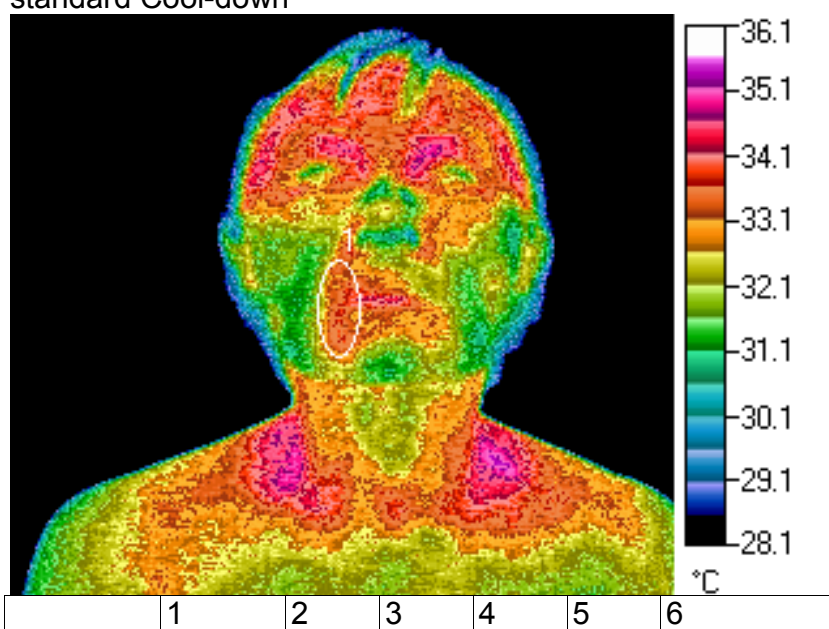

\begin{tabular}{|c|c|c|c|c|c|c|c|c|c|c|c|c|c|}
\hline Type & Circle & \begin{tabular}{|l|} 
None \\
\end{tabular} & None & None & None & None & Type & Circle & None & None & None & None & None \\
\hline Maximum & $34.3^{\circ} \mathrm{C}$ & & & & & & Maximum & $33.8^{\circ} \mathrm{C}$ & & & & & \\
\hline Average & $33.3^{\circ} \mathrm{C}$ & & & & & & Average & $33.0^{\circ} \mathrm{C}$ & & & & & \\
\hline Minimum & $31.8^{\circ} \mathrm{C}$ & & & & & & Minimum & $31.5^{\circ} \mathrm{C}$ & & & & & \\
\hline Std. Dev & 0.421 & & & & & & Std. Dev & 0.432 & & & & & \\
\hline
\end{tabular}

cell phone.

2. Anterior Cranial Facial after Talking on an Unprotected Cell Phone for 15 minutes

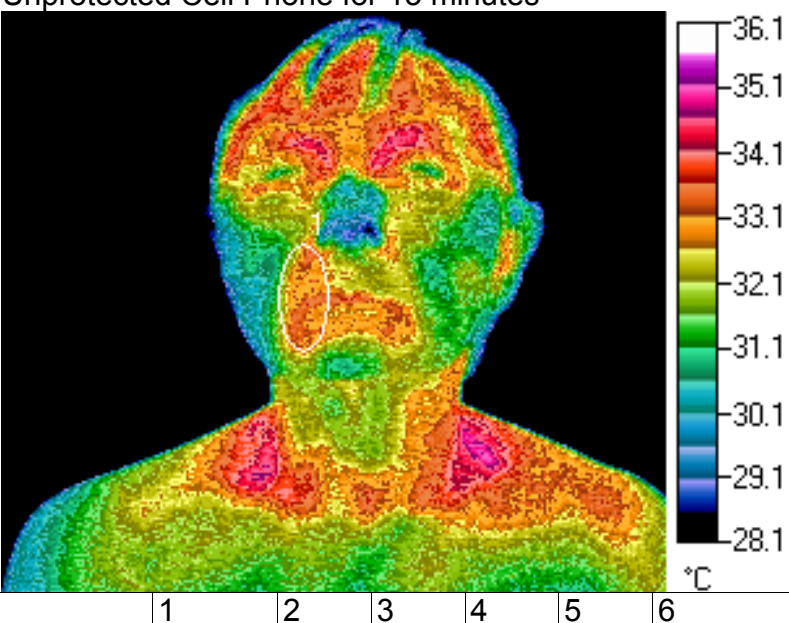

34.1

33.1

32.1

31.1

30.1

29.1

88.1
3. Anterior Cranial Facial after Second standard Cool-down

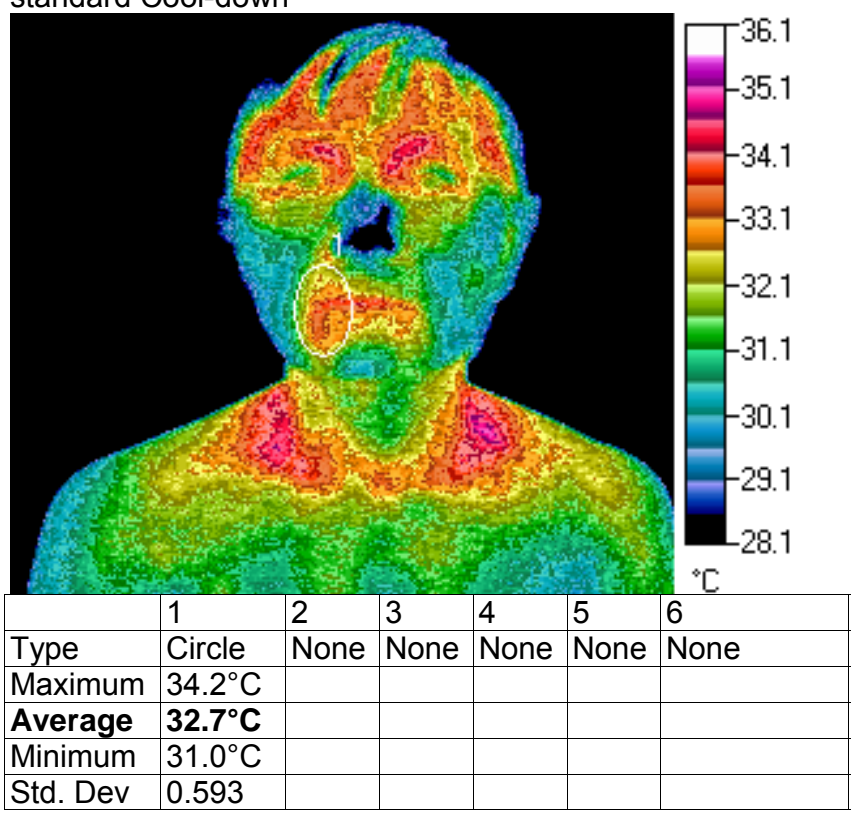

This subject had a lumpectomy in the right breast followed by radiation treatment in 2002. The image after the first standard cool-down also demonstrated the existence of heat patterns in dental area.
4. Anterior Cranial Facial after Talking on a Cell Phone with MRET-Nylon for 15 minutes

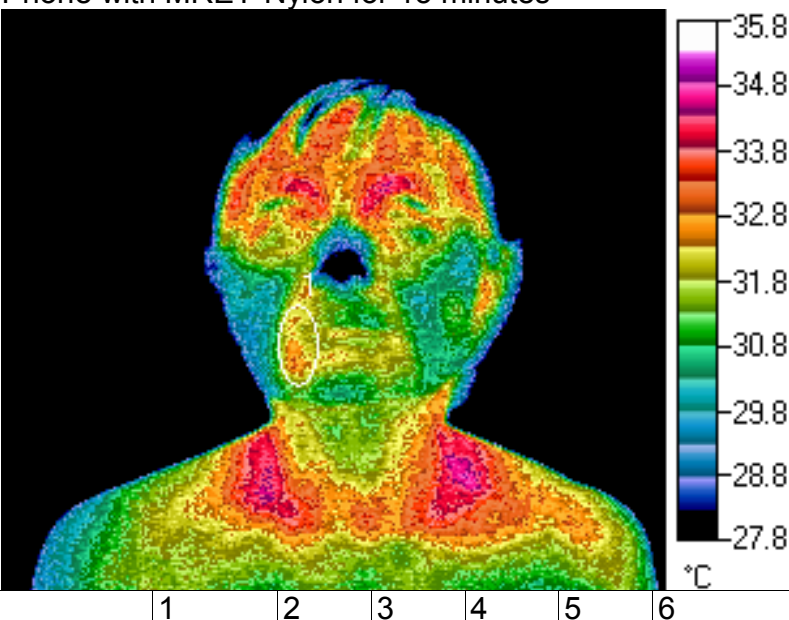

Type Circle None None None None None

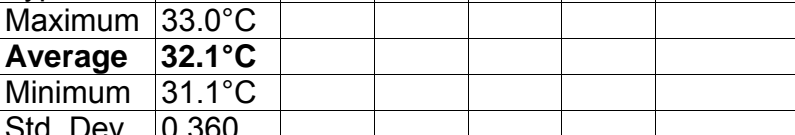

The comparison of the first two images shows no significant changes in the heat patterns following the exposure to unprotected cell phone radiation and even a slight decrease of heat in the mouth area by 
$0.3^{\circ} \mathrm{C}$ (images $1 \& 2$, circle 1 ). The comparison of the second two images shows the significant reduction of the mouth heat by $0.6^{\circ} \mathrm{C}$ (images $3 \& 4$, circle 1 ) on the right side and by $1.0^{\circ} \mathrm{C}$ on the left side (images 3 $\& 4$, color scale) after the installation of the MRETNylon device on the cell phone.
1. Lateral Left Cranial Facial after First standard Cool-down

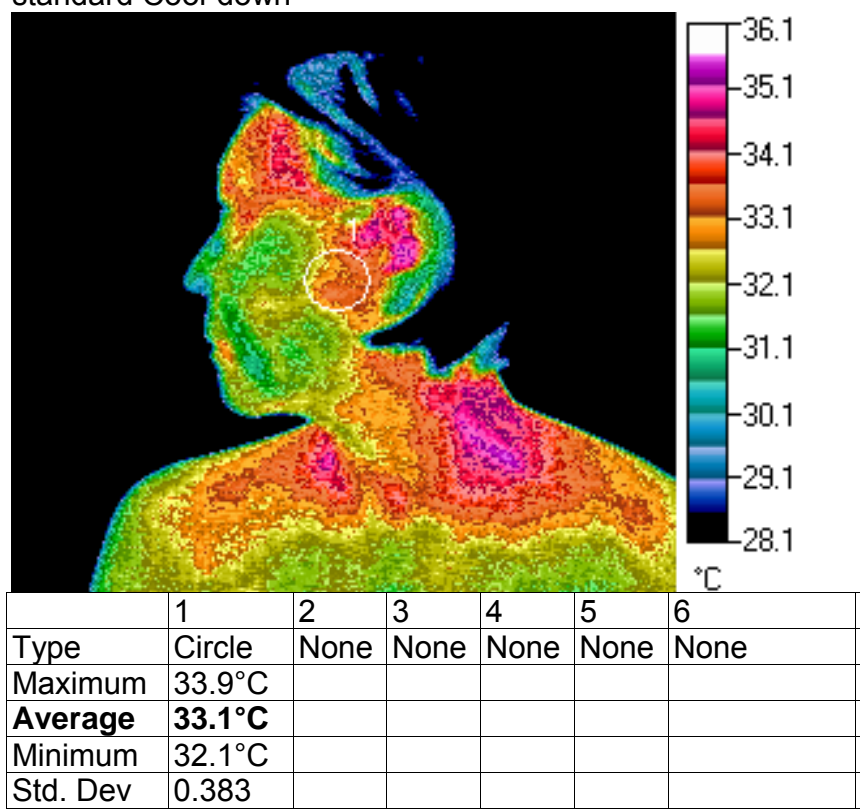

2. Lateral Left Cranial Facial after Talking on an Unprotected Cell Phone for 15 minutes

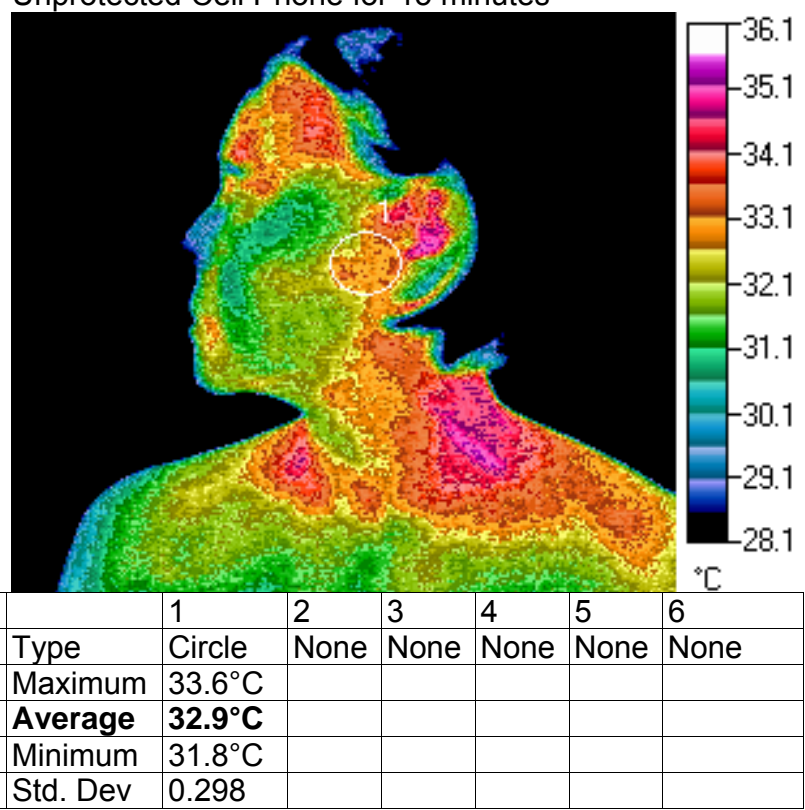

4. Lateral Left Cranial Facial after Talking on a Cell Phone with MRET-Nylon for 15 minutes

\section{Second Cool-down}

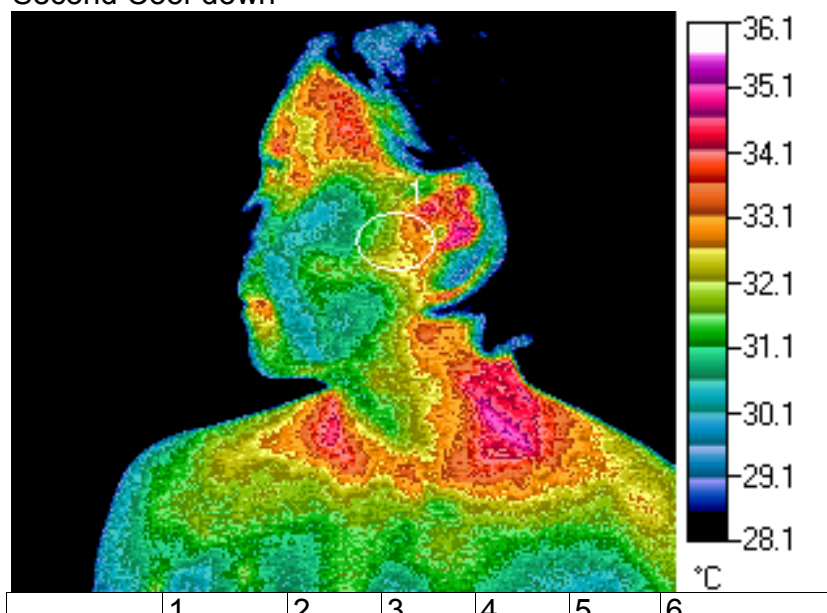

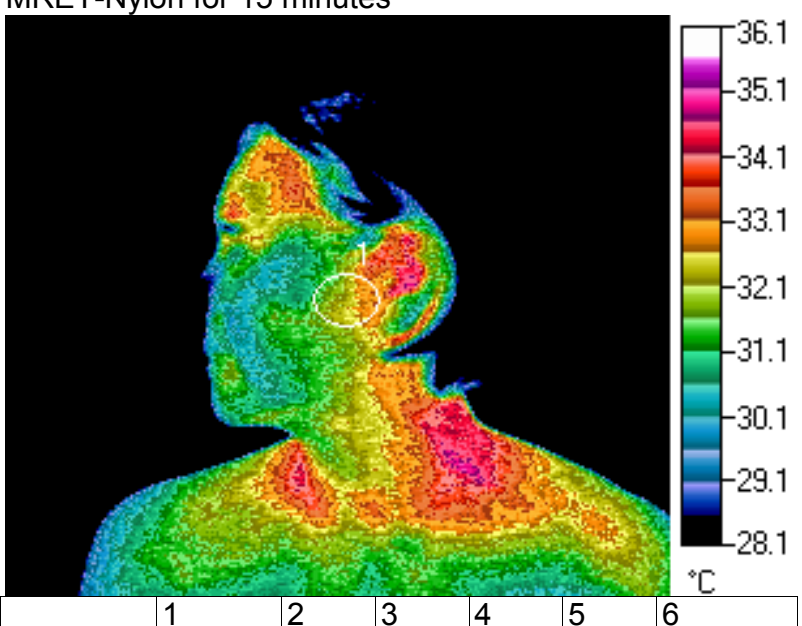

\begin{tabular}{l|l|l|l|l} 
Type & Circle & None & None None None None
\end{tabular}

\begin{tabular}{|c|c|c|c|c|c|c|c|c|c|c|c|c|c|}
\hline Type & Circle & None & None & None & None & None & Type & Circle & None & None & None & None & None \\
\hline Maximum & $33.7^{\circ} \mathrm{C}$ & & & & & & Maximum & $33.2^{\circ} \mathrm{C}$ & & & & & \\
\hline Average & $32.3^{\circ} \mathrm{C}$ & & & & & & Average & $32.3^{\circ} \mathrm{C}$ & & & & & \\
\hline Minimum & $30.9^{\circ} \mathrm{C}$ & & & & & & Minimum & $31.1^{\circ} \mathrm{C}$ & & & & & \\
\hline Std. Dev & 0.589 & & & & & & Std. Dev & 0.506 & & & & & \\
\hline
\end{tabular}

The subject talked on the phone using her left ear. The comparison of the first two images does not show significant changes in the heat patterns following the exposure to the radiation from an unprotected cell phone. The comparison of the second two images shows very significant reduction 
of heat in the left dental area by $1.0^{\circ} \mathrm{C}$ (images $3 \& 4$, color scale) after the installation of the MRET-Nylon

device on the cell phone.

2. Lateral Right Cranial Facial after Talking on an

standard Cool-down
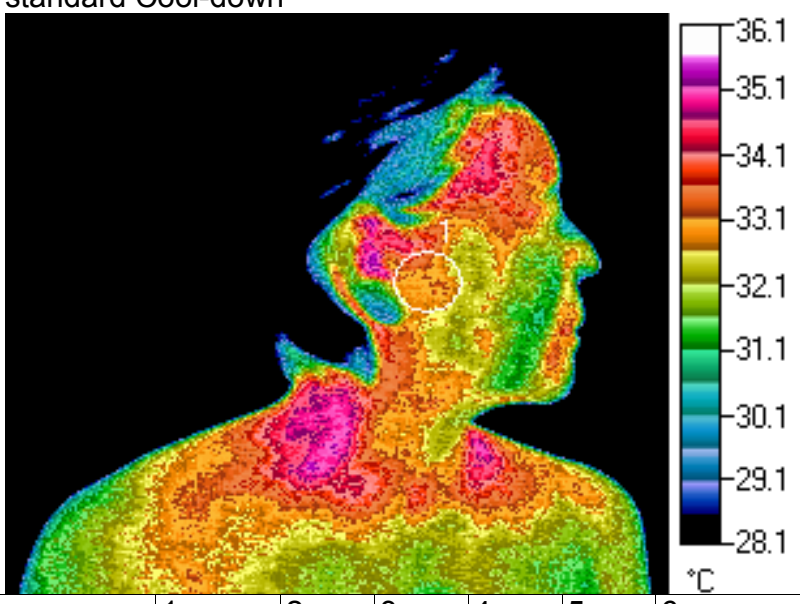

\section{Unprotected Cell Phone for 15 minutes}

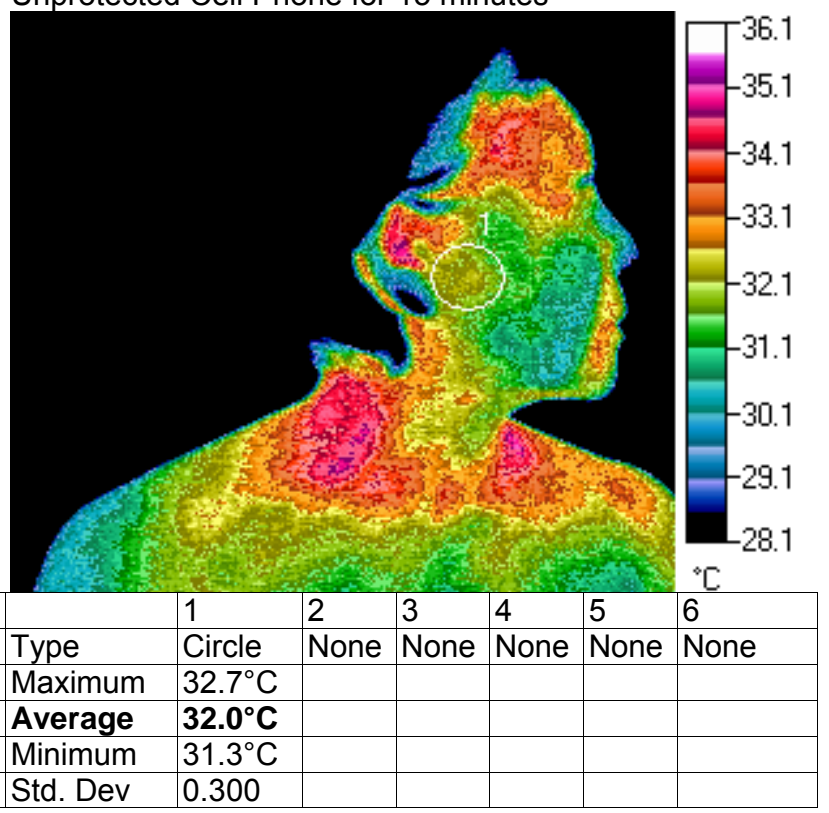

4. Lateral Right Cranial Facial after Talking on a Cell Phone with MRET-Nylon for 15 minutes

\section{Second Cool-down}

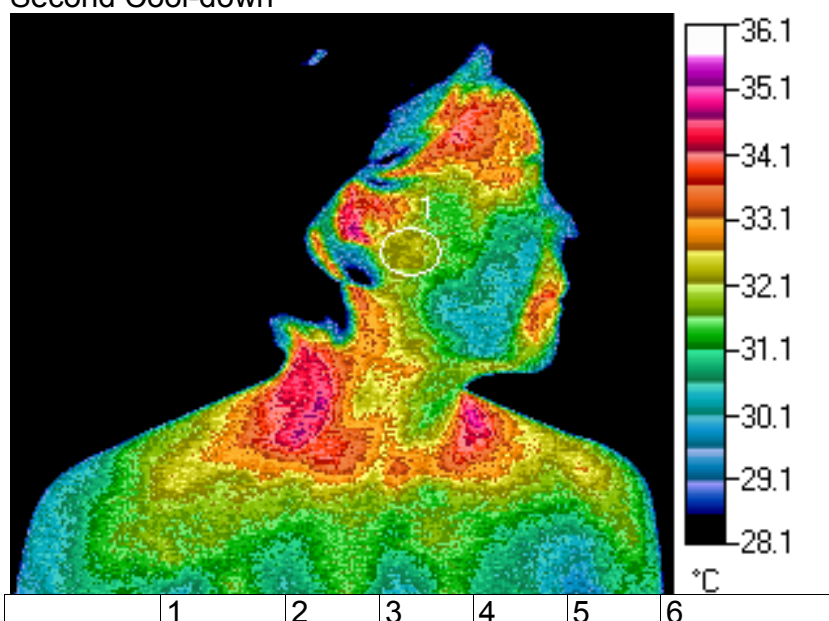

\begin{tabular}{|l|l|l|l|l|l|l|l|l|l|l|l|l|l|l|}
\hline & 1 & 2 & 3 & 4 & 5 & 6 & & 1 & 2 & 3 & 4 & 5 & 6 \\
\hline Type & Circle & None & None & None & None & None & Type & Circle & None & None & None & None & None \\
\hline Maximum & $32.6^{\circ} \mathrm{C}$ & & & & & & Maximum & $32.2^{\circ} \mathrm{C}$ & & & & & \\
\hline Average & $\mathbf{3 2 . 1 ^ { \circ } \mathrm { C }}$ & & & & & & Average & $\mathbf{3 1 . 7 ^ { \circ } \mathbf { C }}$ & & & & & \\
\hline Minimum & $31.4^{\circ} \mathrm{C}$ & & & & & & Minimum & $30.9^{\circ} \mathrm{C}$ & & & & & \\
\hline Std. Dev & 0.248 & & & & & & Std. Dev & 0.289 & & & & & \\
\hline
\end{tabular}

The comparison of the first two images shows significant cooling in the parasympathetic otic ganglion near the ear by $1.0^{\circ} \mathrm{C}$ (images $1 \& 2$, circle 1) following the exposure to the radiation from an unprotected cell phone (abnormal reaction). The comparison of the second two images shows the significant reduction of heat in the left dental area by $1.0^{\circ} \mathrm{C}$ (images $3 \& 4$, color scale) after the installation of the MRET-Nylon device on the cell phone. 
This experiment confirms the significant improvement of thermal patterns in dental area following the Subject No.5:

1. Anterior Cranial Facial after First standard Cool-down
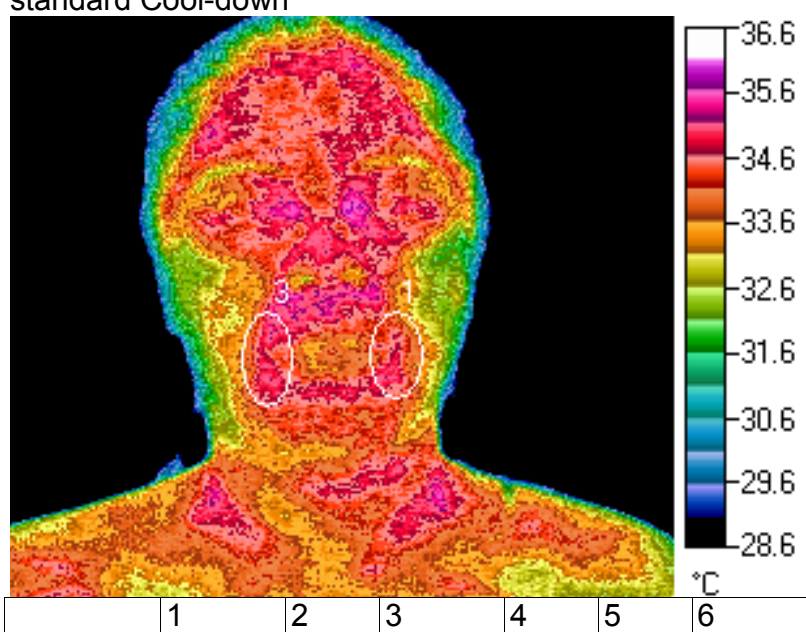

application of the MRET-Nylon device to the cell phone.

2. Anterior Cranial Facial after Talking on Unprotected Cell Phone for 15 minutes

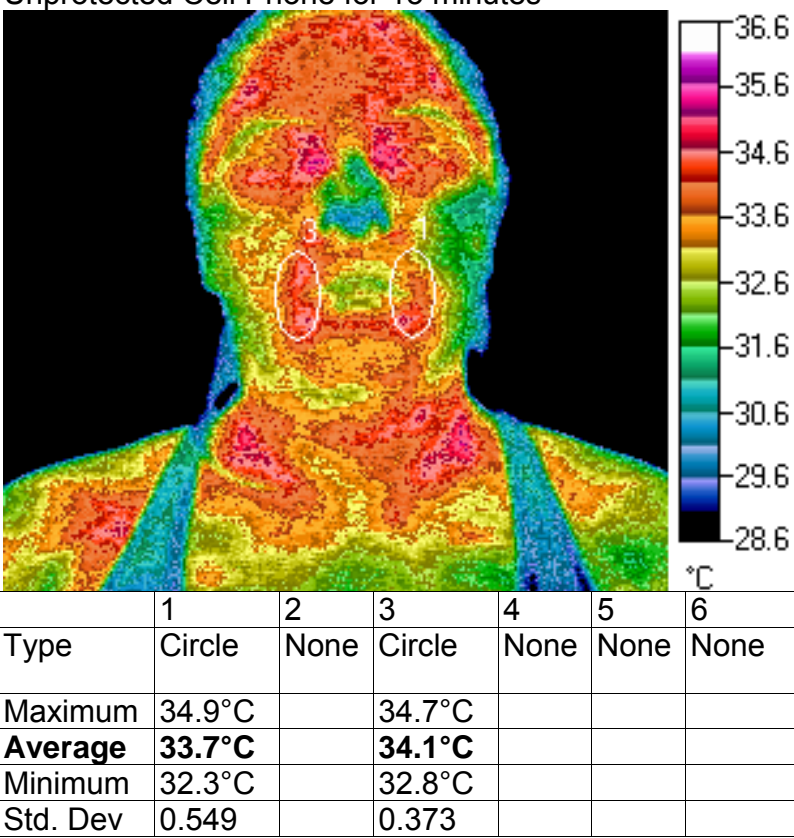

4. Anterior Cranial Facial after Talking on Cell Phone with MRET-Nylon for 15 minutes

\section{Second Cool-down}
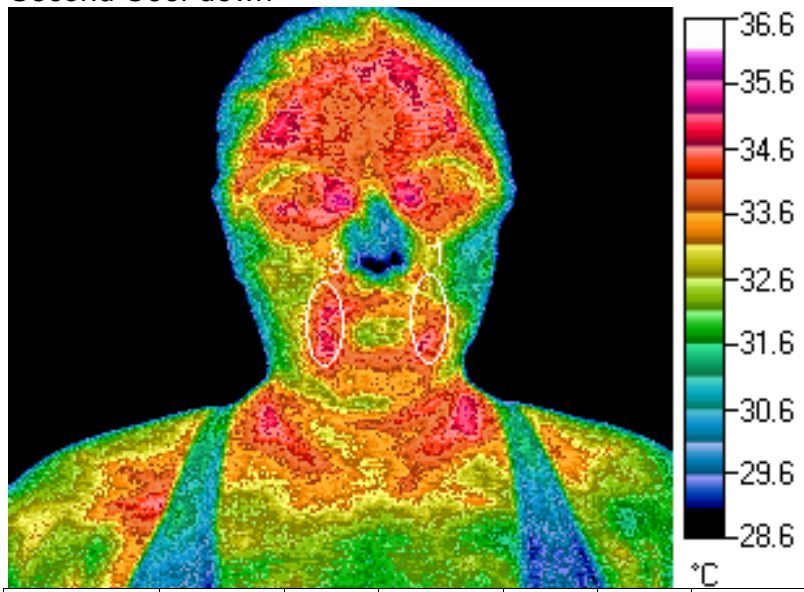

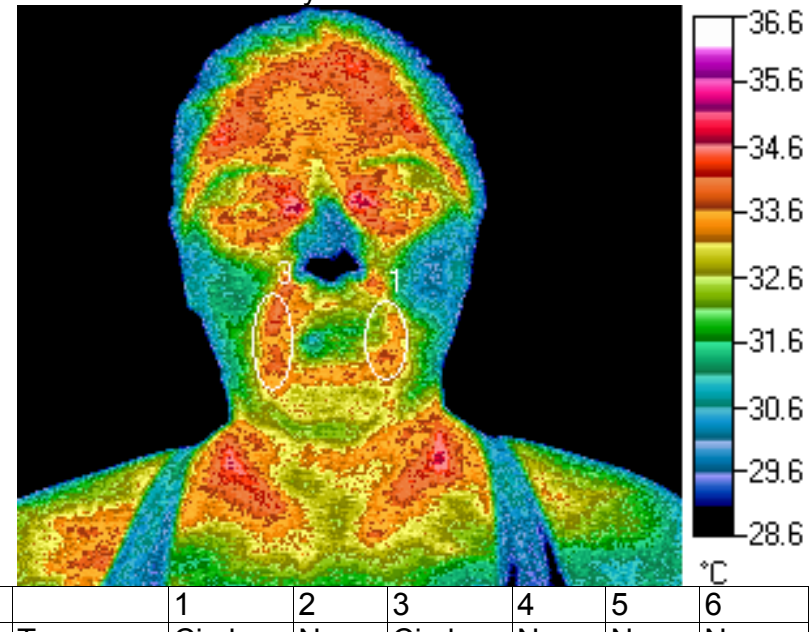

\begin{tabular}{l|l|l|l|l|} 
Type & Circle & None & Circle & None None None
\end{tabular}

\begin{tabular}{|l|l|l|l|l|l|l|}
\hline Type & Circle & None & Circle & None & None & None \\
\hline Maximum & $34.0^{\circ} \mathrm{C}$ & & $34.2^{\circ} \mathrm{C}$ & & & \\
\hline Average & $33.1^{\circ} \mathrm{C}$ & & $33.4^{\circ} \mathrm{C}$ & & & \\
\hline Minimum & $32.0^{\circ} \mathrm{C}$ & & $32.1^{\circ} \mathrm{C}$ & & & \\
\hline Std. Dev & 0.446 & & 0.428 & & & \\
\hline
\end{tabular}

This subject had a recent surgery and she is taking antibiotics. She works in a Wi-Fi environment in a hotel. The image after the first cool-down presents the typical hot face that is common for people working or living in a Wi-Fi environment. She demonstrates abnormal and unstable cooling reaction following the radiation exposure to an unprotected cell phone. There was a decrease of 
heat by $0.5^{\circ} \mathrm{C}-0.8^{\circ} \mathrm{C}$ in the mouth area (images $1 \&$ 2 , circles $1 \& 3$ ) and by $0.5^{\circ} \mathrm{C}-2.5^{\circ} \mathrm{C}$ all over the face, neck and clavicle areas (image $1 \& 2$, color scale) compared with the heat patterns after the first cool-down. This is an indication of exhaustion of the autonomic nervous system due to the combination of continuous stresses from recent surgery, prescription drugs and working in wireless environment.

1. Lateral Right Cranial Facial after First standard Cool-down

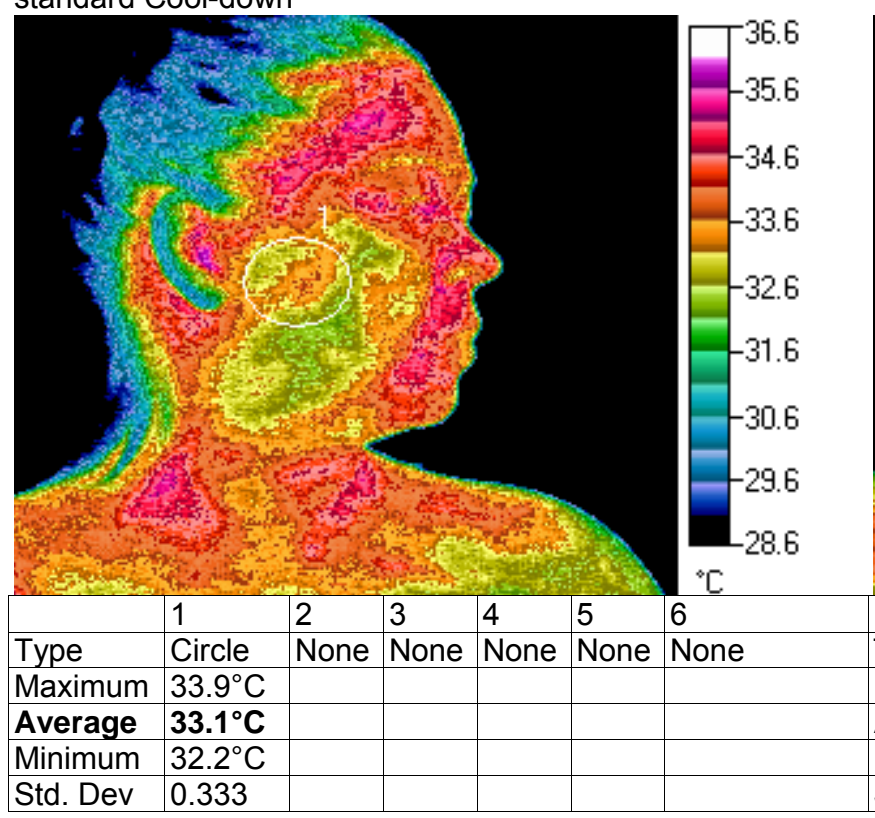

3. Lateral Right Cranial Facial After Second Cool-down

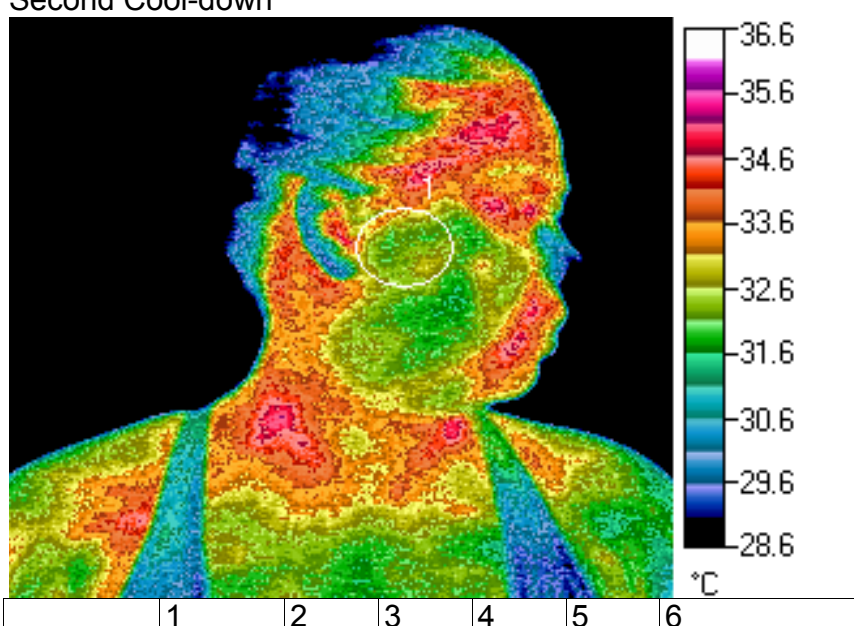

\begin{tabular}{|l|l|l|l|l|l|l|l|l|l|l|l|l|l|l|}
\hline & 1 & 2 & 3 & 4 & 5 & 6 & & 1 & 2 & 3 & 4 & 5 & 6 \\
\hline Type & Circle & None & None & None & None & None & Type & Circle & None & None & None & None & None \\
\hline Maximum & $33.7^{\circ} \mathrm{C}$ & & & & & & Maximum & $33.6^{\circ} \mathrm{C}$ & & & & & \\
\hline Average & $\mathbf{3 2 . 5 ^ { \circ } \mathrm { C }}$ & & & & & & Average & $\mathbf{3 2 . 3 ^ { \circ } \mathbf { C }}$ & & & & & \\
\hline Minimum & $31.8^{\circ} \mathrm{C}$ & & & & & & Minimum & $31.0^{\circ} \mathrm{C}$ & & & & & \\
\hline Std. Dev & 0.366 & & & & & & Std. Dev & 0.536 & & & & & \\
\hline
\end{tabular}

After using a cell phone with the MRET-Nylon chip the heat also significantly reduced, but the rates of this reduction were less and much more stable. There was a decrease of heat by $0.5^{\circ} \mathrm{C}-0.6^{\circ} \mathrm{C}$ in the mouth area (images $1 \& 2$, circles $1 \& 3$ ) and by $0.5^{\circ} \mathrm{C}-1.0^{\circ} \mathrm{C}$ all over the face, neck and clavicle areas (images $1 \& 2$, color scale) compared with the heat patterns after the second cool-down.

2. Lateral Right Cranial Facial after Talking on Unprotected Cell Phone for 15 minutes

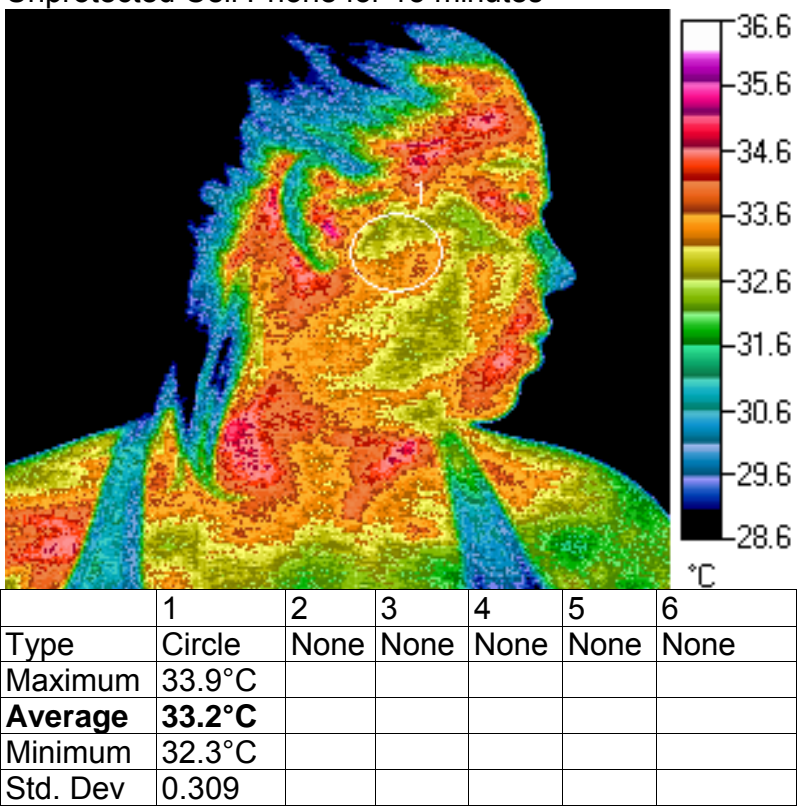

4. Lateral Right Cranial Facial after Talking on Cell Phone with MRET-Nylon for 15 minutes

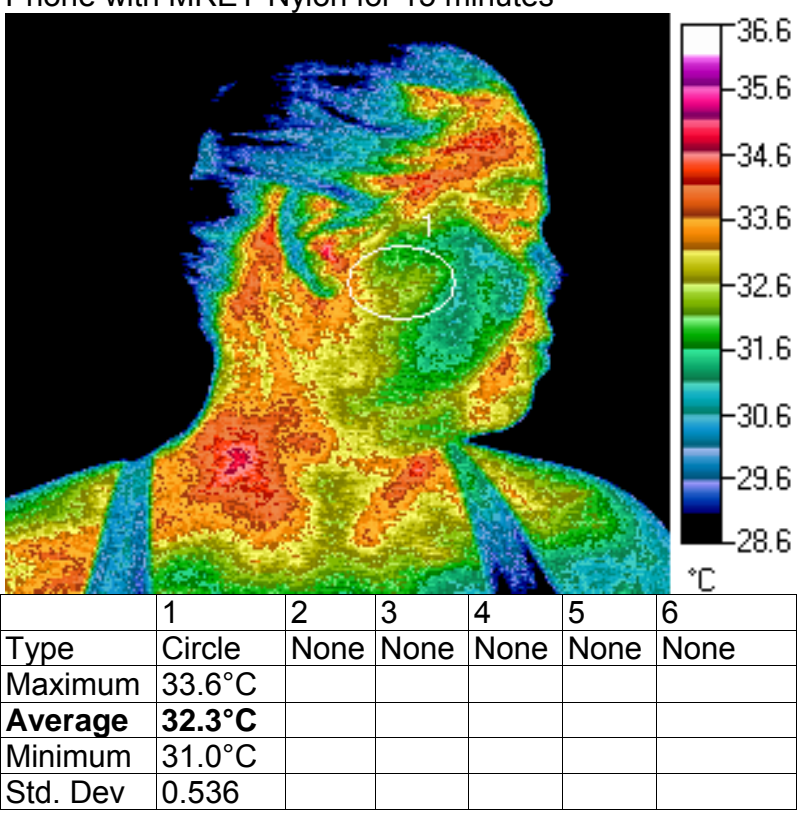


The subject talked on the phone using her right ear. The images of the right side show the same abnormal and unstable cooling patterns as the anterior facial reactions in the range of $0.5^{\circ} \mathrm{C}-2.5^{\circ} \mathrm{C}$ all over the face, neck and clavicle areas (images $1 \&$

1. Lateral Left Cranial Facial after First standard Cool-down

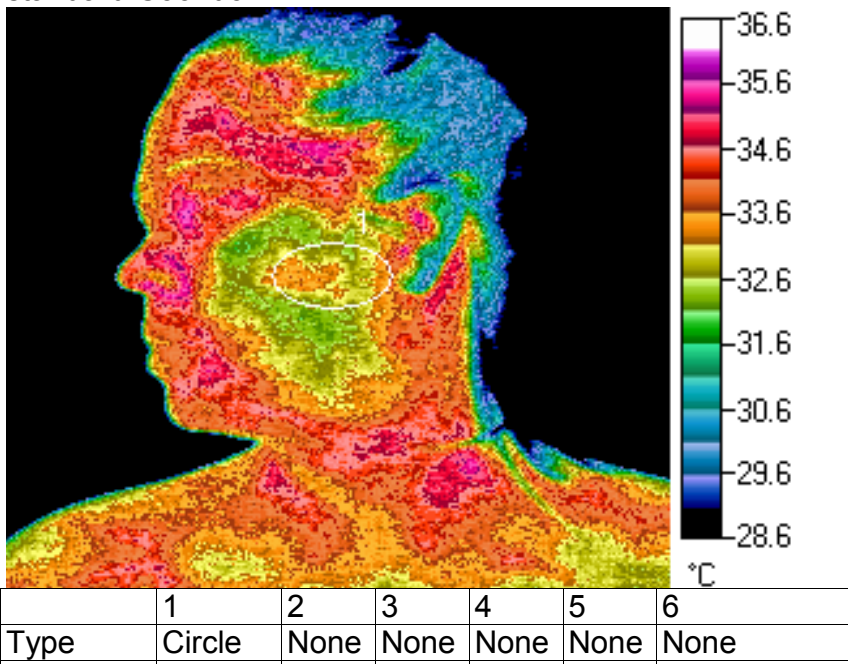

\begin{tabular}{|l|l|l|l|l|l|l|}
\hline Maximum & $33.9^{\circ} \mathrm{C}$ & & & & & \\
\hline Average & $33.0^{\circ} \mathrm{C}$ & & & & & \\
\hline Minimum & $32.3^{\circ} \mathrm{C}$ & & & & &
\end{tabular}

Std. Dev 0.338

3. Lateral Left Cranial Facial After Second Cool-down

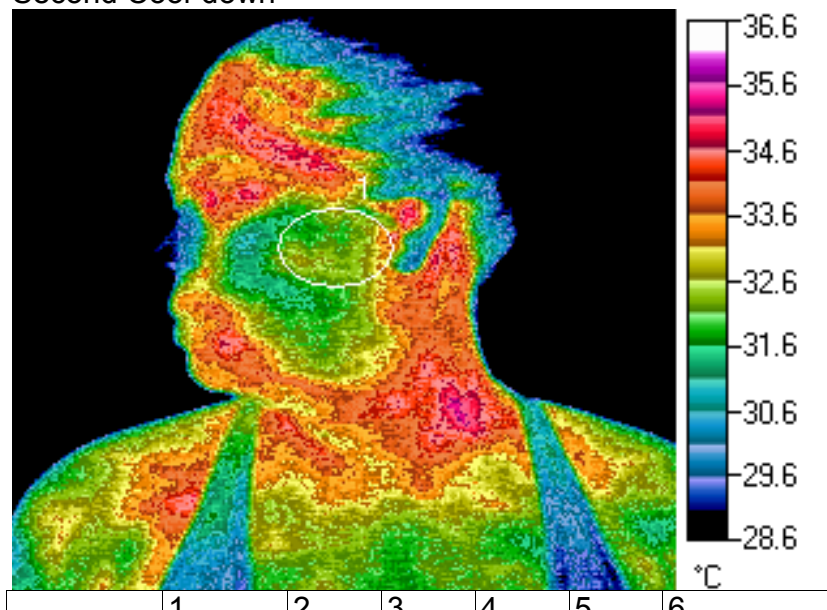

\begin{tabular}{|l|l|l|l|l|l|l|l|}
\hline & 1 & 2 & 3 & 4 & 5 & 6 \\
\hline Type & Circle & None & None & None & None & None \\
\hline Maximum & $34.5^{\circ} \mathrm{C}$ & & & & & & \\
\hline Average & $\mathbf{3 2 . 4 ^ { \circ } \mathbf { C }}$ & & & & & & \\
\hline Minimum & $31.4^{\circ} \mathrm{C}$ & & & & & & \\
\hline Std. Dev & 0.442 & & & & & & \\
\hline
\end{tabular}

The images of the right side show the same abnormal and unstable cooling patterns as the
2, color scale). Following the application of the MRET-Nylon chip to the cell phone the rates of cooling were less and much more stable: $0.5^{\circ} \mathrm{C}-$ $1.0^{\circ} \mathrm{C}$ all over the face, neck and clavicle areas (images $1 \& 2$, color scale).

\section{Lateral Left Cranial Facial after Talking on}

Unprotected Cell Phone for 15 minutes

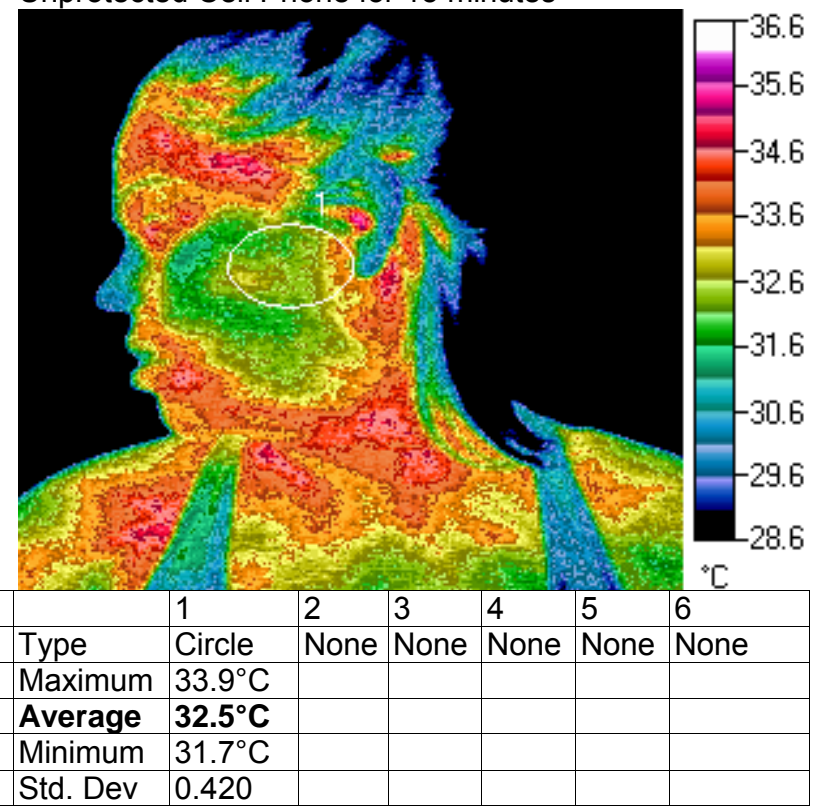

4. Lateral Left Cranial Facial after Talking on Cell

Phone with MRET-Nylon for 15 minutes

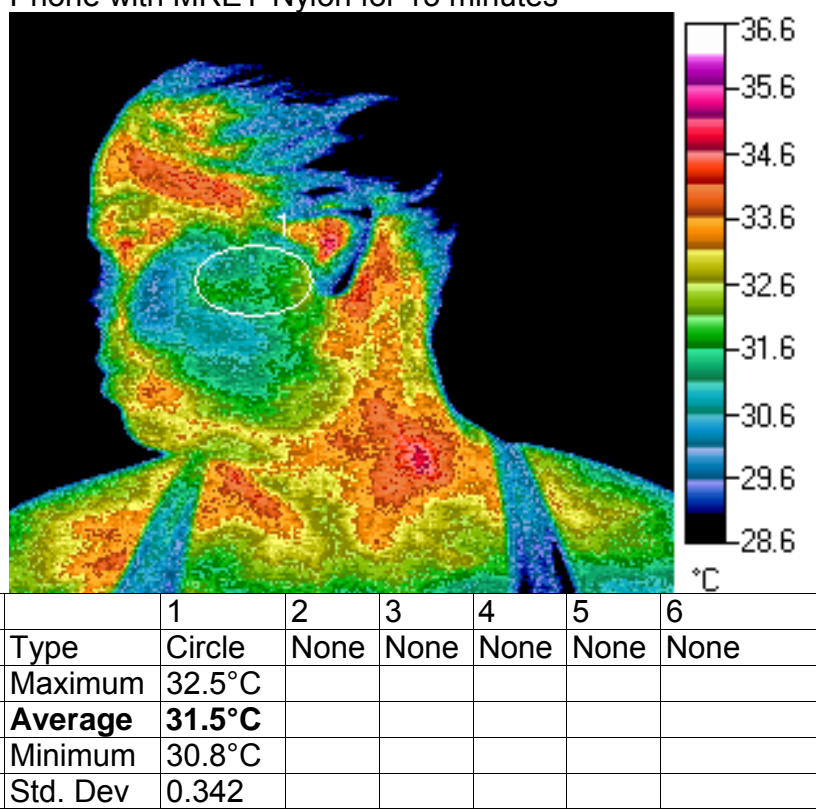

anterior facial reactions in the range of $0.5^{\circ} \mathrm{C}-2.5^{\circ} \mathrm{C}$ all over the face, neck and clavicle areas (images $1 \&$ 
2, color scale). Following the application of the MRET-Nylon chip to the cell phone the rates of cooling were less and much more stable: $0.5^{\circ} \mathrm{C}-$ $1.0^{\circ} \mathrm{C}$ all over the face, neck and clavicle areas (images $1 \& 2$, color scale).

This experiment confirms that the combination of continuous stresses from recent surgery, prescription Subject No. 6:

1. Anterior Cranial Facial after First standard Cool-down

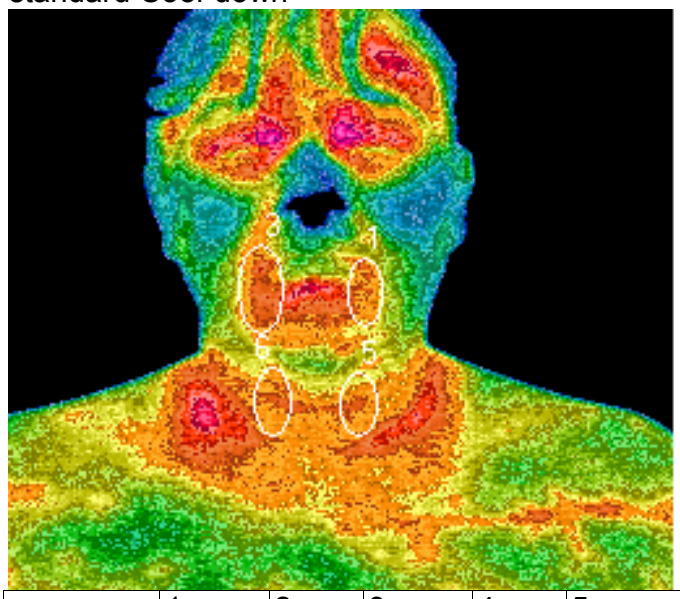

\begin{tabular}{|l|l|l|l|l|l|l|}
\hline & 1 & 2 & 3 & 4 & 5 & 6 \\
\hline Type & Circle & None & Circle & None & Circle & Circle \\
\hline
\end{tabular}

\begin{tabular}{l|l|l|l} 
Maximum $34.4^{\circ} \mathrm{C}$ & $34.6^{\circ} \mathrm{C}$
\end{tabular}

Average $33.6^{\circ} \mathrm{C}$

Minimum $32.7^{\circ} \mathrm{C}$

$\begin{array}{ll}\text { Std. Dev } & 0.313\end{array}$

3. Anterior Cranial Facial After

Second Cool-down

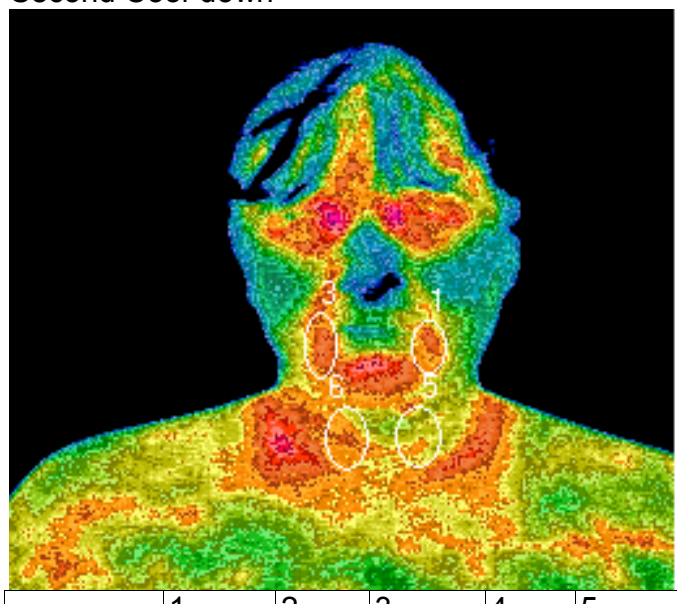

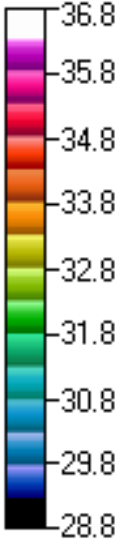

drugs and working in wireless environment may negatively affect the reactions of autonomic nervous system, make them unstable and abnormal. The application of MRET-Nylon improved the reactions of exhausted autonomic system to the EMR exposure, stabilized its reactions and showed significant reduction of thermal effects.

2. Anterior Cranial Facial after Talking on an Unprotected Cell Phone for 15 minutes

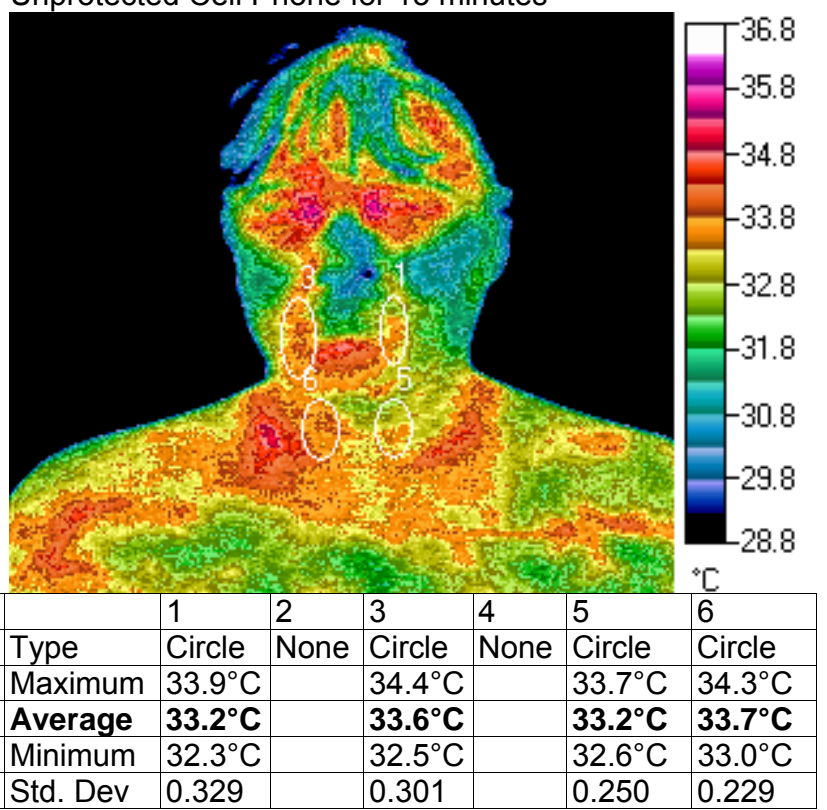

4. Anterior Cranial Facial after Talking on a Cell Phone with MRET-Nylon for 15 minutes
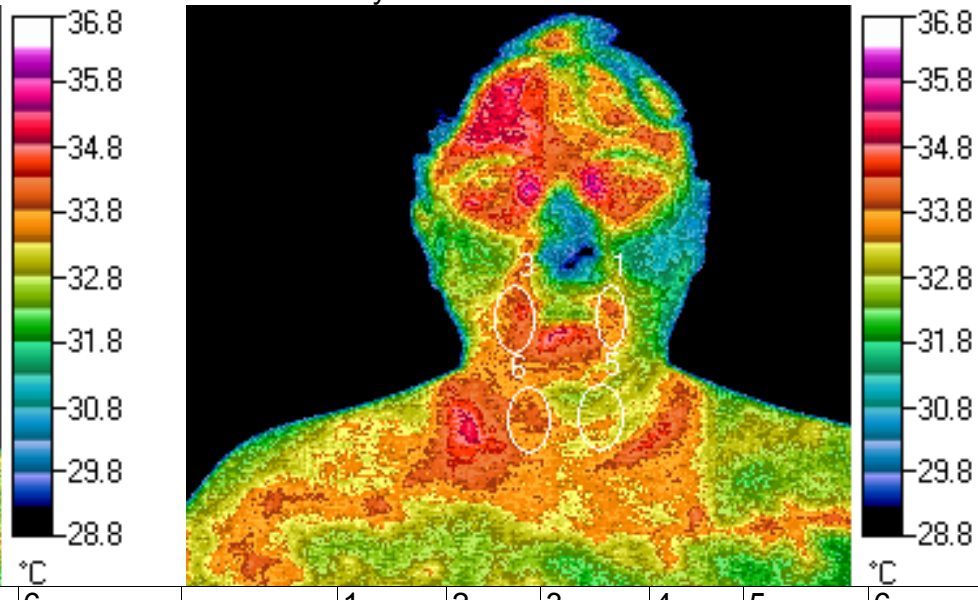

\begin{tabular}{|c|c|c|c|c|c|c|c|c|c|c|c|c|c|}
\hline & 1 & 2 & 3 & 4 & 5 & 6 & & 1 & 2 & 3 & 4 & 5 & 6 \\
\hline Type & Circle & None & Circle & None & Circle & Circle & Type & Circle & None & Circle & None & Circle & Circle \\
\hline Maximum & $34.4^{\circ} \mathrm{C}$ & & $34.5^{\circ} \mathrm{C}$ & & $33.9^{\circ} \mathrm{C}$ & $34.2^{\circ} \mathrm{C}$ & Maximum & $34.2^{\circ} \mathrm{C}$ & & $34.8^{\circ} \mathrm{C}$ & & $33.7^{\circ} \mathrm{C}$ & $34.2^{\circ} \mathrm{C}$ \\
\hline Average & $33.6^{\circ} \mathrm{C}$ & & $33.8^{\circ} \mathrm{C}$ & & $33.2^{\circ} \mathrm{C}$ & $33.6^{\circ} \mathrm{C}$ & Average & $33.5^{\circ} \mathrm{C}$ & & $34.0^{\circ} \mathrm{C}$ & & $33.2^{\circ} \mathrm{C}$ & $33.8^{\circ} \mathrm{C}$ \\
\hline Minimum & $32.7^{\circ} \mathrm{C}$ & & $32.7^{\circ} \mathrm{C}$ & & $32.6^{\circ} \mathrm{C}$ & $32.6^{\circ} \mathrm{C}$ & Minimum & $32.8^{\circ} \mathrm{C}$ & & $33.2^{\circ} \mathrm{C}$ & & $32.4^{\circ} \mathrm{C}$ & $33.1^{\circ} \mathrm{C}$ \\
\hline Std. Dev & 0.326 & & 0.322 & & 0.266 & 0.276 & Std. Dev & 0.350 & & 0.260 & & 0.239 & 0.217 \\
\hline
\end{tabular}


This woman has many health problems and was taking prescription drugs for many years. She used birth control pills for 25 years, takes Prevacid for heartburn, Fluoxetine for depression and Diabend for high blood pressure. Over the last ten years thermology studies (particularly for reflex sympathetic dystrophy caused by an autonomic dysfunction) have shown that pharmaceutical drug use does affect the autonomic nervous system. Chronic drug use could lead to the exhaustion and destabilization of the autonomic nervous system resulting in its abnormal reactions to the stresses, particular to the stress caused by exposure to EMR, such as unstable

1. Lateral Right Cranial Facial after First standard Cool-down

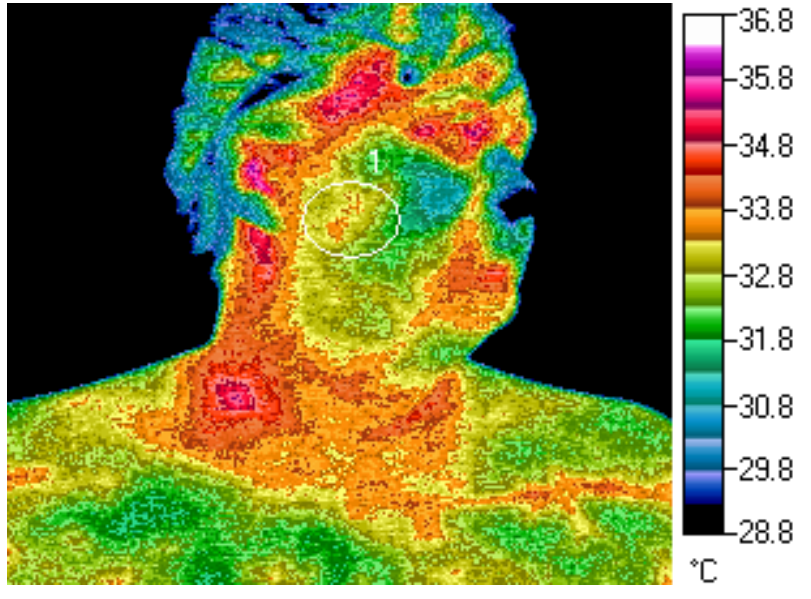

reactions, the absence of any thermal reactions to the stresses or even abnormal cooling. This experiment confirms such suggestion.

Following the exposure to an unprotected cell phone the majority of thermal patterns changed in abnormal direction: the head area was cooled by $0.5^{\circ} \mathrm{C}-1.0^{\circ} \mathrm{C}$ (images $1 \& 2$, color scale) and the left lobe of the thyroid was cooled by $0.5^{\circ} \mathrm{C}$ (image $1 \& 2$, circle 5 ), only the nasal heat increased by $0.5^{\circ} \mathrm{C}$ (images $1 \& 2$, color scale). Following the exposure to a cell phone protected with MRET-Nylon chip the heat in the head increased by $1.5^{\circ} \mathrm{C}-2.5^{\circ} \mathrm{C}$ and the heat patterns in other areas practically did not change

2. Lateral Right Cranial Facial after Talking on an Unprotected Cell Phone for 15 minutes

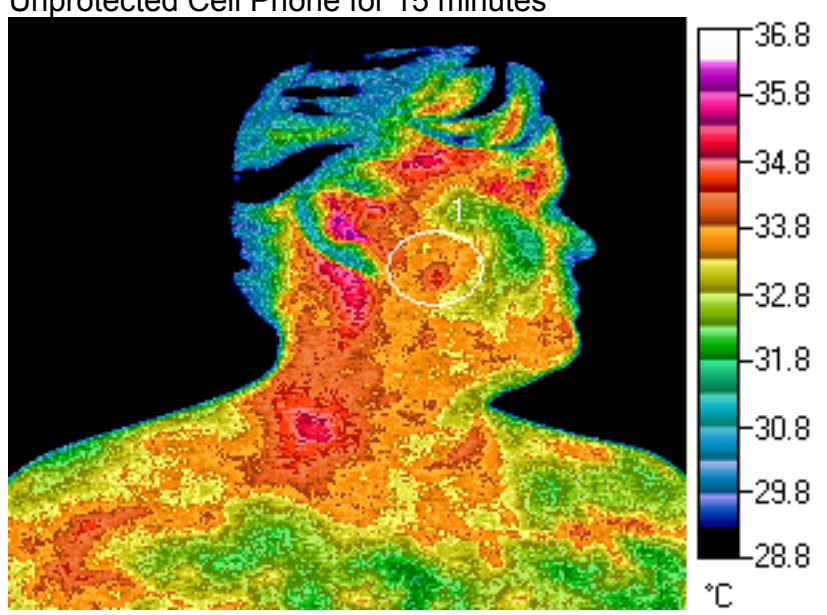

\begin{tabular}{|l|l|l|l|l|l|l|l|l|l|l|l|l|l|}
\hline & 1 & 2 & 3 & 4 & 5 & 6 & & 1 & 2 & 3 & 4 & 5 & 6 \\
\hline Type & Circle & None & None & None & None & None & Type & Circle & None & None & None & None & None \\
\hline Maximum & $33.9^{\circ} \mathrm{C}$ & & & & & & Maximum & $34.5^{\circ} \mathrm{C}$ & & & & & \\
\hline Average & $\mathbf{3 2 . 9 ^ { \circ } \mathbf { C }}$ & & & & & & Average & $\mathbf{3 3 . 6 ^ { \circ } \mathbf { C }}$ & & & & & \\
\hline Minimum & $31.5^{\circ} \mathrm{C}$ & & & & & & Minimum & $32.8^{\circ} \mathrm{C}$ & & & & & \\
\hline Std. Dev & 0.422 & & & & & & Std. Dev & 0.320 & & & & & \\
\hline
\end{tabular}


3. Lateral Right Cranial Facial After

Second Cool-down

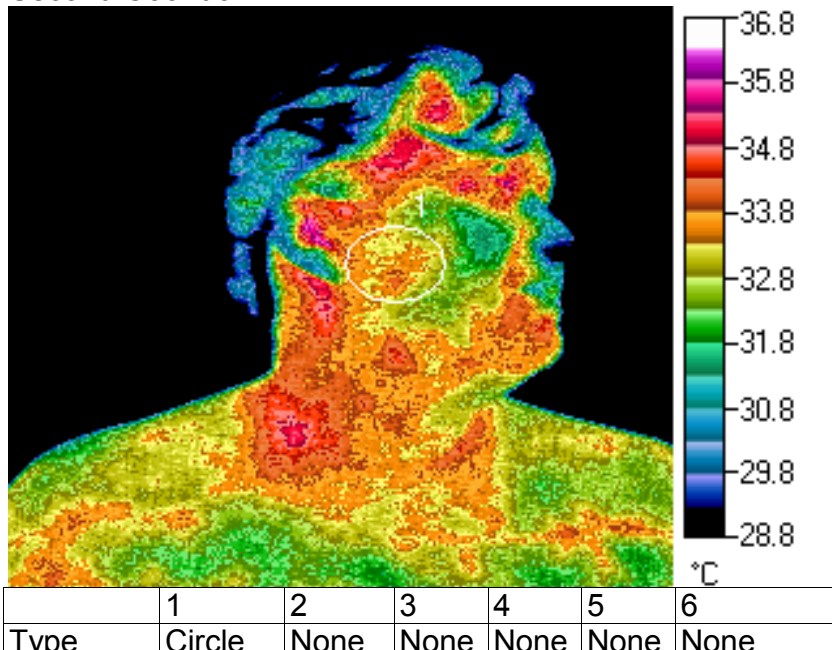

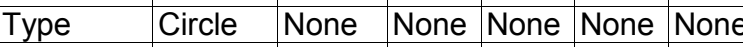

Maximum $34.2^{\circ} \mathrm{C}$

Average $33.3^{\circ} \mathrm{C}$

Minimum $32.4^{\circ} \mathrm{C}$

Std. Dev 0.324
4. Lateral Right Cranial Facial after Talking on a Cell Phone with MRET-Nylon for 15 minutes

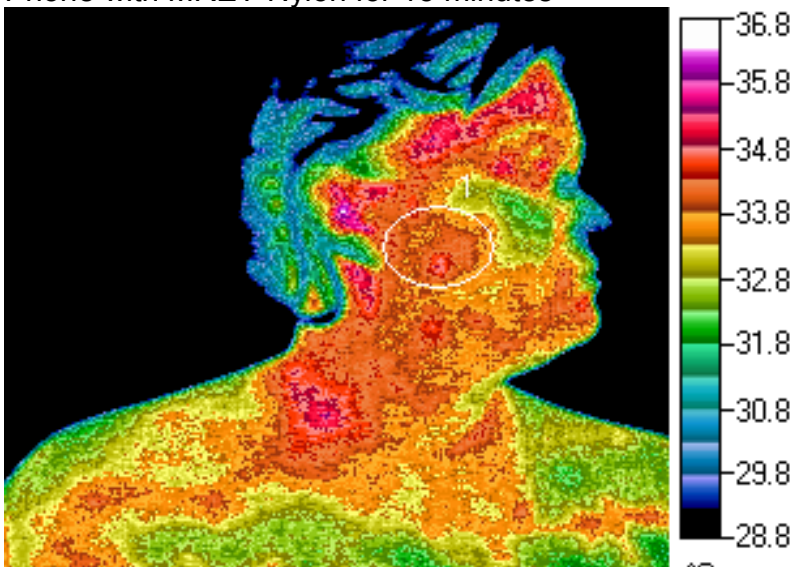

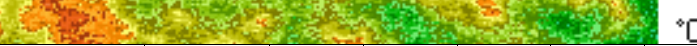

\begin{tabular}{l|l|l|l|l|l} 
Type & Circle & None & None & None None & None
\end{tabular}

Average $34.0^{\circ} \mathrm{C}$

Minimum $33.1^{\circ} \mathrm{C}$

Std. Dev 0.271

This woman talked on the phone using the right ear. There was a typical increase of heat in the parasympathetic otic ganglion near the ear by $0.7^{\circ} \mathrm{C}$ and in the submaxillary glands in the right cheek - chin areas after the exposure to the cell phone radiation in both cases (images $1 \& 2$, circle 1 and images $3 \& 4$, circle 1 ).
1. Lateral Left Cranial Facial after First standard Cool-down

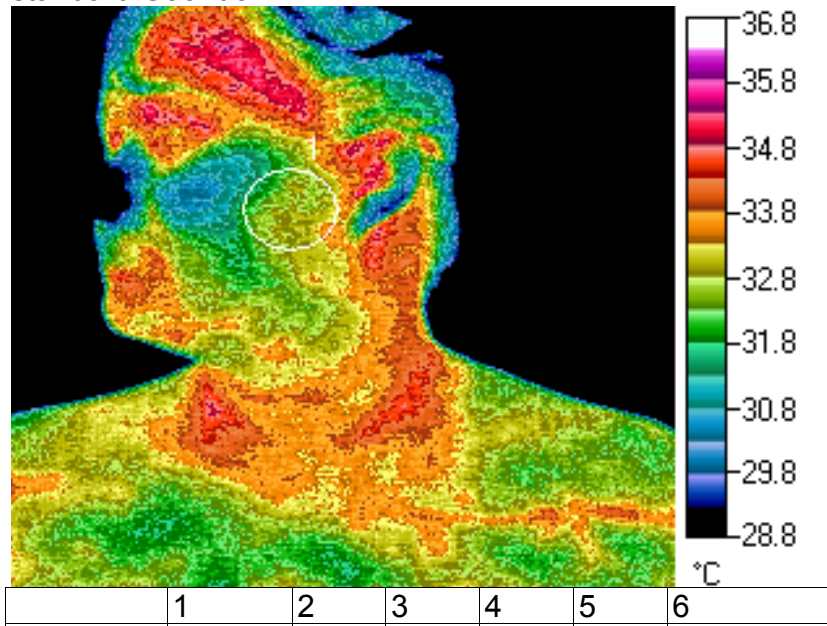

\begin{tabular}{|l|l|l|l|l|l}
\hline Type & Circle & None & None & None & None \\
\hline
\end{tabular}

Maximum $33.9^{\circ} \mathrm{C}$

\begin{tabular}{l|l|l}
\hline Average & $32.7^{\circ} \mathrm{C}$ \\
\hline
\end{tabular}

$\begin{array}{ll}\text { Minimum } & 31.4^{\circ} \mathrm{C}\end{array}$

Std. Dev 0.431
2. Lateral Left Cranial Facial after Talking on Unprotected Cell Phone for 15 minutes

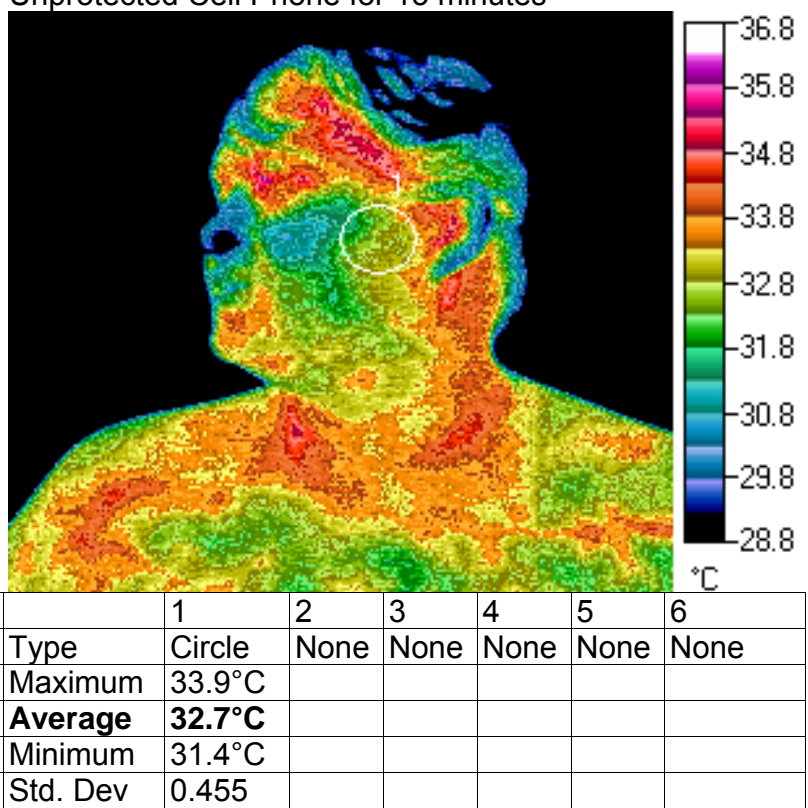


3. Lateral Left Cranial Facial After

\section{Second Cool-down}

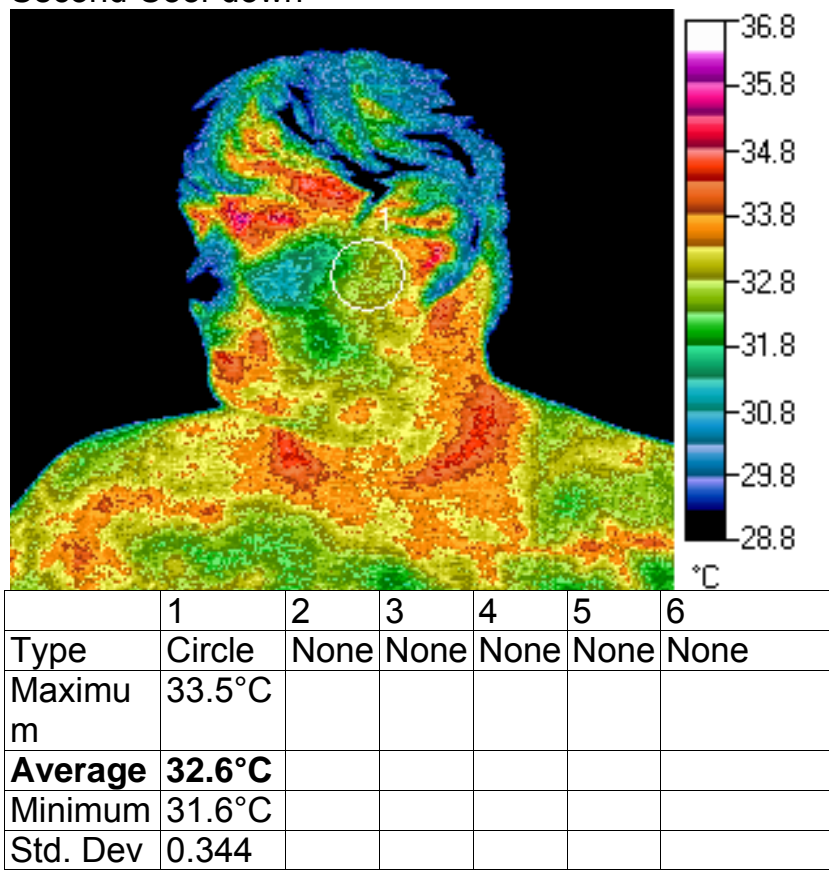

4. Lateral Left Cranial Facial after Talking on Cell Phone with MRET-Nylon for 15 minutes

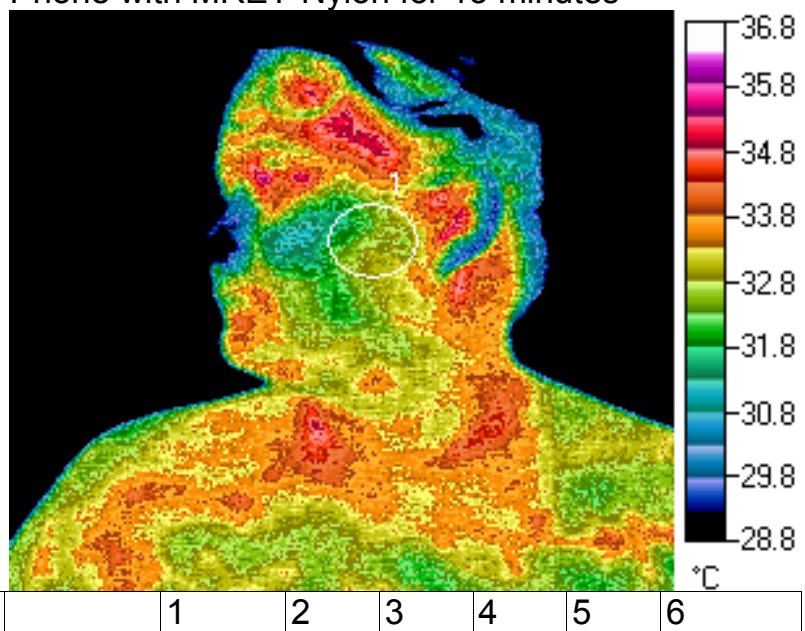

Type Circle None None None None None m

Average $32.6^{\circ} \mathrm{C}$ Minimum $31.3^{\circ} \mathrm{C}$ Std. Dev 0.425

There were no significant changes on the left side following the radiation exposure in both cases.

This experiment confirms that continuous usage of prescription drugs for several years can weaken the autonomic nervous system to the point where abnormal and unstable responses are triggered by the exposure to EMR. In this case the subject demonstrated unstable and abnormal reactions following the exposure to the radiation from an unprotected cell phone. The application of the MRETNylon did not enhance the abnormal reactions of the subject to the EMR exposure.

\section{Subject No. 7:}

The three pairs of thermography images were taken from this subject. They were as following:
1) After the First Cool-down and After Talking on an Unprotected cell phone for 15 minutes;

2) After the Second Cool-down and After Talking on MRET-Nylon Protected cell phone for 15 minutes;

3) After the Third Cool-down and After Talking on MRET-Shield Protected cell phone for 15 minutes;

MRET-Shield device is based on Molecular Resonance Effect Technology and covered with US Patent "Electromagnetic radiation Shielding Material and Device." It was used by the general public since 2002. The MRET-Nylon device belongs to the new generation of electromagnetic radiation shielding materials and devices based on Molecular Resonance Effect Technology. 
1. Anterior Cranial Facial after First standard Cool-down

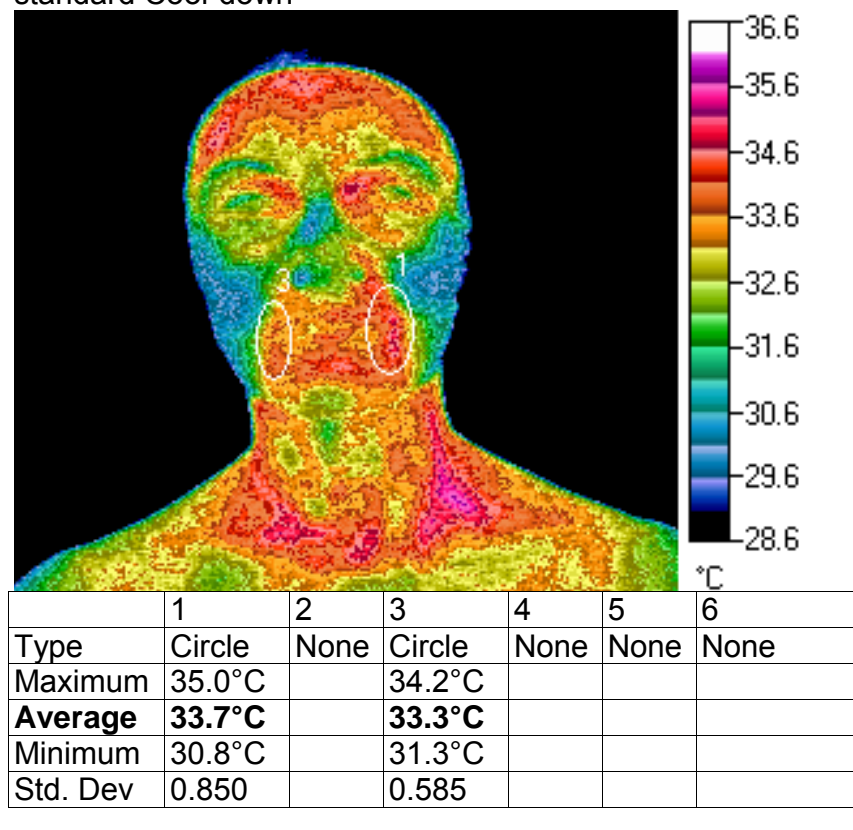

2. Anterior Cranial Facial after Talking on Unprotected Cell Phone for 15 minutes

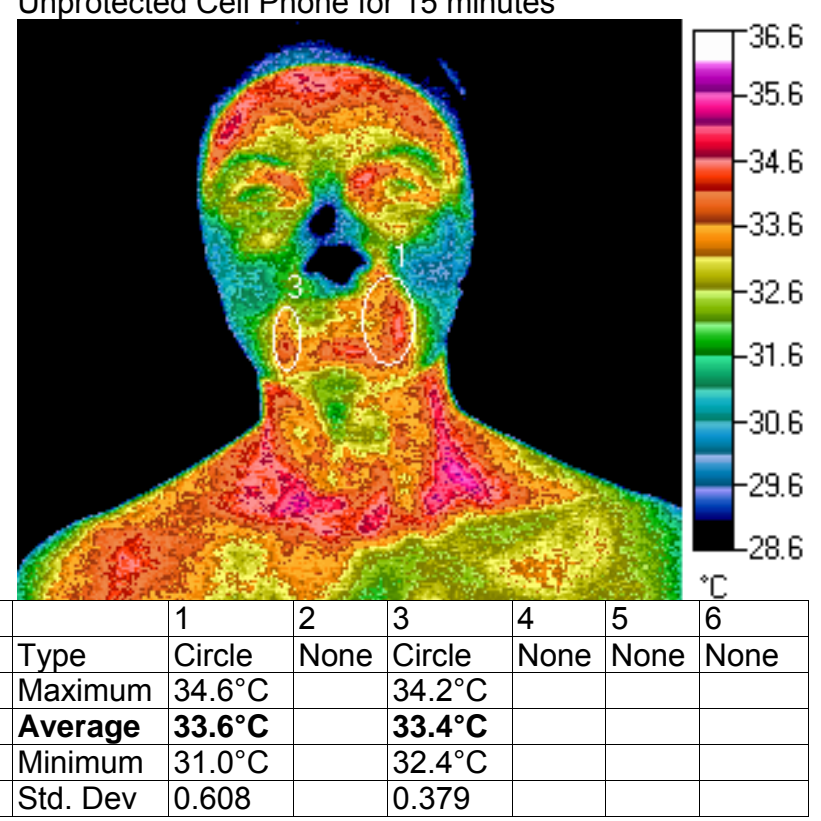

3. Anterior Cranial Facial After Second Cool-down

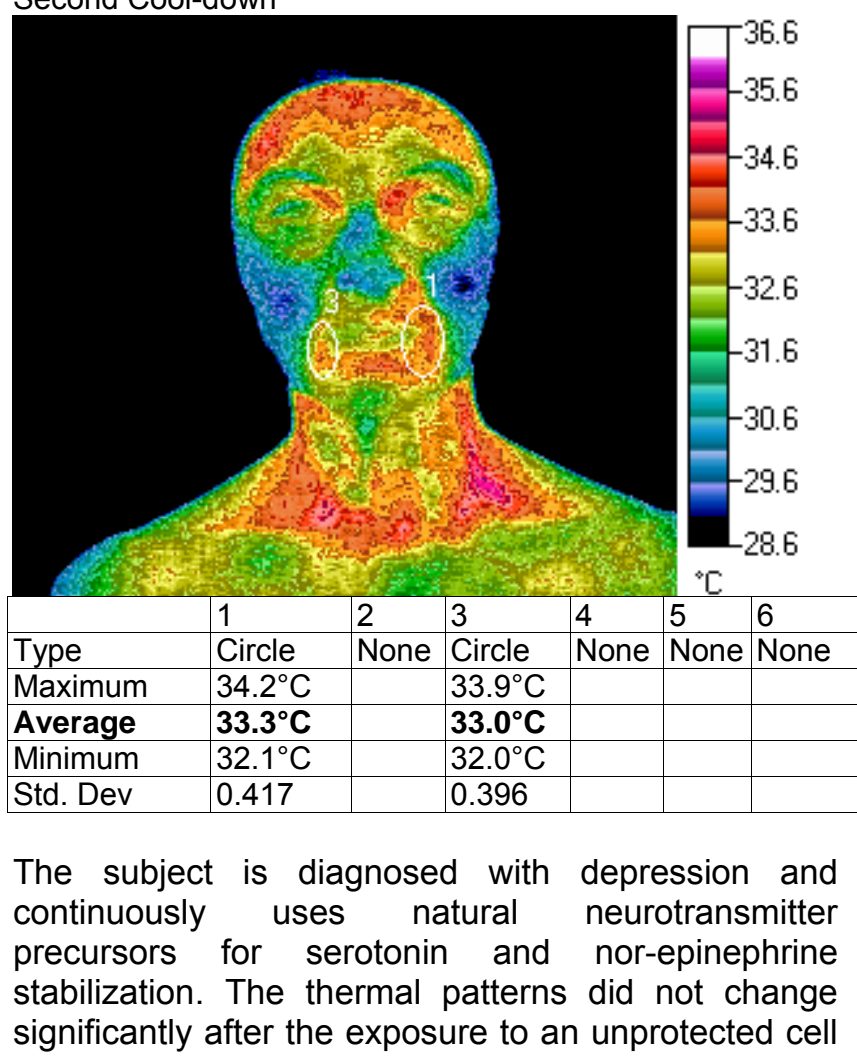

4. Anterior Cranial Facial after Talking on Cell Phone with MRET-Nylon for 15 minutes

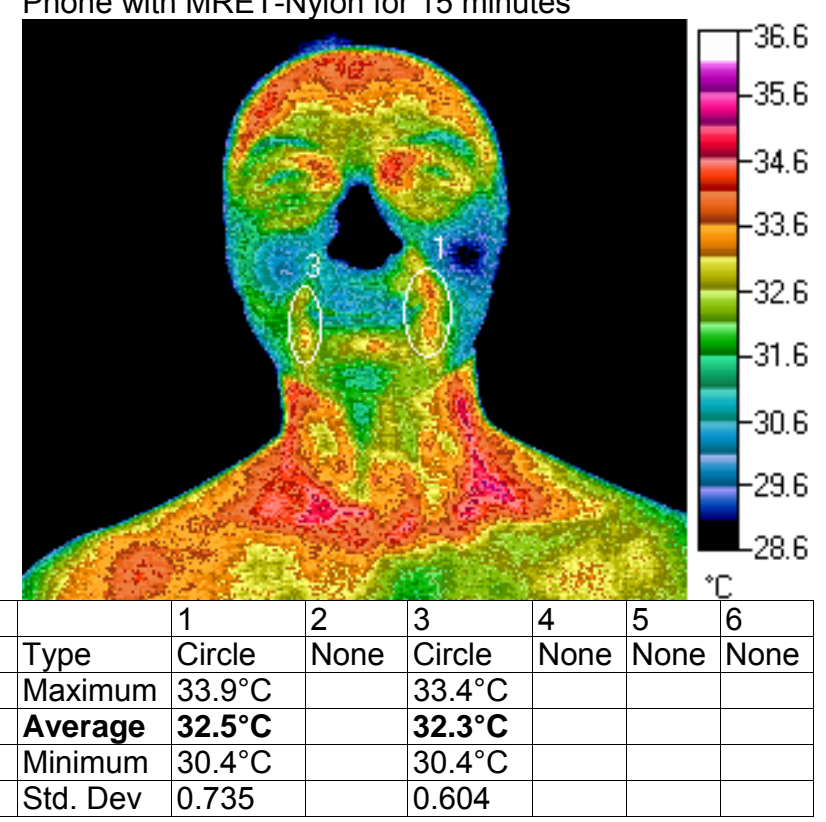

phone except for abnormal slight decrease of heat in the nasal area up to $0.5^{\circ} \mathrm{C}$ (images $1 \& 2$, color scale). The subject talked on the phone using her left ear. The image after the first cool-down showed excessive mouth heat in a pattern typical of dental infections (heat invading a sinus). The mouth heat 
was not significantly affected following the exposure to radiation from an unprotected cell phone (images 1 $\& 2$, circles $1 \& 3)$.

The mouth heat did cool down significantly after the application of the MRET-Nylon chip to the cell phone: by $0.8^{\circ} \mathrm{C}$ on the left side (image $3 \& 4$, circle 1 ) and by $0.7^{\circ} \mathrm{C}$ on the right side (image $3 \& 4$, circle 3 ) comparing with the image after the second cool-down. The heat in nasal - left cheek area also cooled significantly by $1.5^{\circ} \mathrm{C}-2.0^{\circ} \mathrm{C}$ (image $3 \& 4$, color scale).

This experiment confirms the significant reduction of thermal effects and the improvement of thermal patterns in dental - nasal - cheek areas following the installation of the MRET-Nylon device on the cell phone.

\section{Anterior Cranial Facial After} Third Cool-down

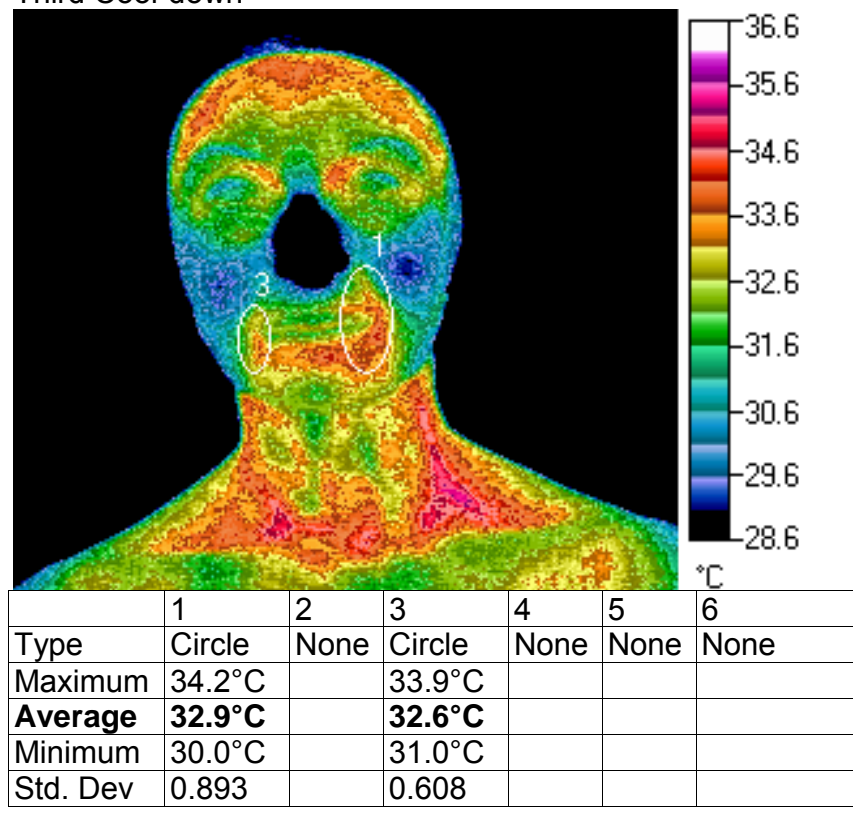

The comparison of thermography images related to two different EMR protective devices MRET-Nylon and MRET-Shield show the following results. The application of MRET-Nylon chip to a cell phone significantly reduced the heat in nasal - left cheek area and in mouth area comparing to the second standard cool-down. During the third standard cooldown the heat continued to decrease in eyes - nasal - cheeks areas and the mouth heat slightly increased but did not achieved the heat level following the second cool-down. These facts confirm that MRET-Nylon device has the long-term EMR protective beneficial effects.

Then the subject talked on a cell phone with MRETShield device. The heat in left cheek area continued to decrease by $0.5^{\circ} \mathrm{C}$ (image $5 \& 6$, color scale) and the mouth heat also reduced by $1.1^{\circ} \mathrm{C}$ on the left
6. Anterior Cranial Facial after Talking on Cell

Phone with MRET-Shield for 15 minutes

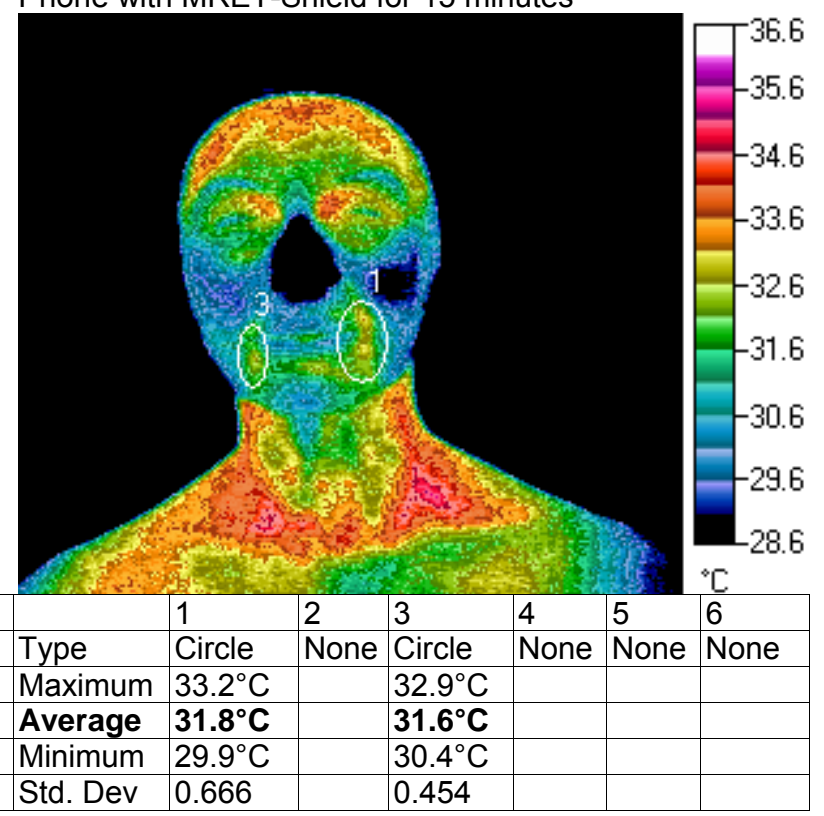

side (image $5 \& 6$, circle 1 ) and by $1.0^{\circ} \mathrm{C}$ on the right side (image $5 \& 6$, circle 2 ).

Comparing the heat reduction rates in case of the application of both EMR protective devices and taking in consideration the long-term effect of MRETShield it is reasonable to conclude that MRET-Nylon and MRET-Shield devices significantly reduce the thermal effects and the rates of reduction are approximately the same.

\section{DISCUSSION}

The current study shows that the exposure of human subjects to the microwave radiation of cellular phone results in the measured increase of the body temperature. It also shows that the installation of the MRET $^{\circledR}$-Nylon protective device on an RF phone significantly reduced or negated the thermal effects 
caused by RF phones and even leaded to the cooling pattern compared to the standard cool-down state. The results of two studies, one regarding the effect of the MRET $^{\circledR}$-Nylon polymer on SAR values of RF phones conducted under the supervision of Jay Moulton in RF Laboratory, Escondido, California, USA and another regarding the effect of the MRET ${ }^{\circledR}$ Nylon device on the blood perfusion rate of the subject exposed to cellular phone radiation conducted by Gabriel Inoue in Japan confirmed that the installation of the MRET ${ }^{\circledR}$-Nylon protective device leaded to reduction of the specific absorption rate as well as to reduction of the range of the blood perfusion rates of subjects exposed to the source of EMR [Smirnov, 2008].

Those result are well correlated with the accepted physical model which explains the relationship between the elevation of the body temperature with increased specific absorption rate of electromagnetic radiation (SAR) and increased blood perfusion rate (Green's function) usually following the human body exposure to EMR. The steady-state temperature elevation of the body can be described by the following bio-heat equation:

$\delta T(r)=\sum_{i} \rho\left(r_{i}\right) S A R\left(r_{i}\right) G\left(r ; r_{i}\right)$

where $G$ is Green's function, the dominant parameter influencing this function is related to the blood perfusion rate; $S A R$ is specific absorption rate of tissue; and $\rho$ is the density of tissue. Considering that the density of tissue is a constant it is possible to conclude that the elevation of the body temperature is directly correlated with increase of specific absorption rate $(S A R)$ and the blood perfusion rate $(G)$ in the body.

SAR is a measure of the rate at which radio frequency (RF) energy is absorbed by the body when exposed to radio-frequency electromagnetic field. It is defined as the power absorbed per mass of tissue and has units of Watts per kilogram. SAR is usually averaged either over the whole body, or over a small sample volume (typically $1 \mathrm{~g}$ or $10 \mathrm{~g}$ of tissue).

Following the equation (1) the thermography experiments confirmed that the exposure to RF phone radiation leaded to the elevation of the body temperature in the area of head, face and neck of the subjects. This temperature elevation resulted from the increase of the specific absorption rate and the blood perfusion rate in the body of the tested subjects.

It is well known that the total blood flow to brain, kidneys, liver, and muscle is very significant with highest perfusion rates to brain, kidney, liver, and heart. On the other hand brain capillaries seem to have impermeable walls restricting the transfer of molecules from blood to brain tissue. Lipid soluble compounds can be readily transferred but the transfer of polar substances is severely restricted. This is the basis of the "blood-brain" barrier. Consequently, the increase of the blood perfusion rate to brain leads to the distortion of the "bloodbrain" barrier function. The increased blood perfusion rate to such organs like heart, liver and kidneys affects the normal homeostasis of the body including the function of autonomic nervous system.

Following the equation (1) the thermography experiments also confirmed that the installation of MRET ${ }^{\circledR}$-Nylon device on the RF phone leaded to significant reduction or negation of thermal effects caused by RF phones and even to the cooling patterns compared to the standard cool-down state. The temperature reduction resulted from the decrease of the specific absorption rate and the blood perfusion rate in the body of the tested subjects. Consequently, the decrease of blood perfusion rate to such organs like heart, liver and kidneys following the application of $\mathrm{MRET}^{\circledR}$-Nylon devices normalizes the homeostasis of the body including the function of autonomic nervous system.

\section{CONCLUSION}

The normal parasympathetic ganglia in the face respond to radiation stress by heating, as seen in hundreds of thermal studies. Over the last ten years, thermology studies (particularly for reflex sympathetic dystrophy caused by an autonomic dysfunction) have shown that pharmaceutical drug use does affect the autonomic nervous system. Chronic drug use could lead to the exhaustion and destabilization of the autonomic nervous system resulting in its abnormal reactions to the stresses and particularly to the stresses caused by the exposure to EMR.

The observation of thermographic images in all views (anterior, lateral right and lateral left cranial facials) during this study showed an insignificant increase of heat patterns or no substantial reactions after the exposure of subjects to an unprotected cell phone in the majority of studied cases and significant reduction of heat patterns (cooling effects) following the application of the EMR protective MRET-Nylon devices to the cell phone (compared with related images after standard cool-downs).

The main result of this study is the confirmation of significant reduction of thermal effects and 
improvement of thermal patterns following the application of the MRET-Nylon device to a cell phone. The installation of the MRET-Nylon device on a cell phone induced significant heat reduction (cooling effects) following the exposure of the subjects to the cell phone radiation. Thus the application of the MRET-Nylon device to a cell phone contributed to the strengthening and stabilization of the autonomic nervous system.

All studied subjects were patients of Fickes Holistic Care Corp. They had a number of health problems and were continuously using prescription drugs. The abnormally weak reactions to the stress from the exposure to the radiation emitted by a cell phone demonstrated during this investigation confirm that poor health conditions and continuous drug consumption exhaust and destabilize the autonomic nervous system.

The last experiment was conducted first using the MRET-Nylon device and then another EMR protective device the MRET-Shield based on the same Molecular Resonance Effect Technology as the MRET-Nylon. This experiment showed that both devices significantly reduced the thermal effects approximately in the same range and contributed to the strengthening and stabilization of the autonomic nervous system. It also confirmed that the MRETNylon device had the long-term EMR protective beneficial effects.

One of the conducted experiments (subject \#6) confirmed that the continuous usage of prescription drugs for several years can weaken the autonomic nervous system to the point where abnormal and unstable responses are triggered by the exposure to EMR. Many medical doctors have found that the autonomic nervous system imbalances, oversensitivities and injuries cause some of the most difficult problems in medicine. In this case the subject demonstrated unstable and abnormal reactions following the exposure of the subject to the radiation from an unprotected cell phone. The application of the MRET-Nylon device did not enhance the abnormal reactions of the subject to the EMR exposure.

One must be aware that thermal effects constitute only one aspect of problems caused by the exposure to electromagnetic radiation. A number of studies confirm that there are numerous negative physiological effects related to the continuous exposure to EMR. These findings raise the issue of the bioaccumulation of the health related radiation effects when considering that the average individual frequently uses the cell and cordless phones.

\section{REFERENCES}

Adair E.R., Adams B.W., and Akei G.M. (1984) "Minimal changes in hypothalamic temperature accompany microwave-induced alteration of thermoregulatory behavior", Bioelectromagnetics, 5:13-30

IACT. Thermography Guidelines: Standards and Protocols in Clinical Thermographic Imaging. International academy of Clinical Thermology. September 2002. www.iact-org.org/professionals/thermogguidelines.html

Henry Lai, (2004) "Interaction of microwaves and temporally incoherent magnetic field on spatial learning in the rat", Physiology \& Behavior, 82:785-789

Smirnov I V., (2006) "Polymer Material Providing Compatibility between Technologically Originated EMR and Biological Systems" Explore Magazine, 15(4):2632

Smirnov I V., (2008) "The Effect of MRET Polymer Compound on SAR Values of RF Phones" JMPEE, 42(1):42-54

Zeng Q L, Ke Z, Gao X, Fu Y, Lu D, Chiang H, Xu Z (2006) "Noise Magnetic Fields Abolish the Gap Junction Intercellular Communication Suppression Induced by $50 \mathrm{~Hz}$ Magnetic Fields" Bioelectromagnetics, 27(4):274-279 